Review

\title{
An Overview of Epigenetics in Obesity: The Role of Lifestyle and Therapeutic Interventions
}

\author{
Abeer M. Mahmoud (iD \\ Division of Endocrinology, Diabetes, and Metabolism, Department of Medicine, College of Medicine, \\ University of Illinois at Chicago, Chicago, IL 60612, USA; amahmo4@uic.edu
}

check for updates

Citation: Mahmoud, A.M. An Overview of Epigenetics in Obesity: The Role of Lifestyle and Therapeutic Interventions. Int. J. Mol. Sci. 2022, 23, 1341. https://doi.org/10.3390/ ijms23031341

Academic Editors: Gabriella Calviello and Simona Serini

Received: 8 January 2022

Accepted: 24 January 2022

Published: 25 January 2022

Publisher's Note: MDPI stays neutral with regard to jurisdictional claims in published maps and institutional affiliations.

Copyright: (C) 2022 by the author. Licensee MDPI, Basel, Switzerland. This article is an open access article distributed under the terms and conditions of the Creative Commons Attribution (CC BY) license (https:// creativecommons.org/licenses/by/ $4.0 /)$.

\begin{abstract}
Obesity has become a global epidemic that has a negative impact on population health and the economy of nations. Genetic predispositions have been demonstrated to have a substantial role in the unbalanced energy metabolism seen in obesity. However, these genetic variations cannot entirely explain the massive growth in obesity over the last few decades. Accumulating evidence suggests that modern lifestyle characteristics such as the intake of energy-dense foods, adopting sedentary behavior, or exposure to environmental factors such as industrial endocrine disruptors all contribute to the rising obesity epidemic. Recent advances in the study of DNA and its alterations have considerably increased our understanding of the function of epigenetics in regulating energy metabolism and expenditure in obesity and metabolic diseases. These epigenetic modifications influence how DNA is transcribed without altering its sequence. They are dynamic, reflecting the interplay between the body and its surroundings. Notably, these epigenetic changes are reversible, making them appealing targets for therapeutic and corrective interventions. In this review, I discuss how these epigenetic modifications contribute to the disordered energy metabolism in obesity and to what degree lifestyle and weight reduction strategies and pharmacological drugs can restore energy balance by restoring normal epigenetic profiles.
\end{abstract}

Keywords: obesity; epigenetics; energy metabolism; lifestyle; DNA methylation; histone modifications; microRNAs; diet; physical activity; weight loss

\section{Introduction}

Over the last century, science has contributed to an almost three-decade increase in the average person's lifespan. However, the rising obesity prevalence is considered an epidemic that threatens to reduce current and future generations' life expectancy and quality of life [1]. This will also pose a considerable challenge to future healthcare finances. Obesity increases the risk of various comorbidities, including diabetes, cardiovascular disease, and cancer [2]. Furthermore, recent research has found that obese people are more likely to suffer significant repercussions from the overlapping COVID19 pandemic [3]. Therefore, it is crucial to understand the underlying cellular and molecular mechanisms and identify novel therapeutic targets for obesity.

Genome-wide association studies (GWAS) have revealed several hundred genetic loci that are associated with body mass index (BMI); however, these correlations can only explain around $3-5 \%$ of the BMI variance observed in the population [4]. According to the World Health Organization's (WHO) most recent report, worldwide obesity has nearly tripled since 1975. Overweight people account for more than 1.9 billion (39\%) of the adult population, with over 650 million $(13 \%)$ obese. This enormous increase in obesity rates over the last few decades cannot be explained entirely by genetics. Therefore, scientists should look beyond genetics and consider the influence of lifestyle factors and obesogenic environmental exposures and their potential interaction with the genome.

Obesity is currently considered a pandemic due to the surrounding obesogenic environment, including the availability of calorie-dense fast food and recent technological 
advances that significantly diminish daily physical activity [5]. Nevertheless, obesity is still avoidable by improved lifestyle and everyday decisions regarding nutrition, physical exercise, and other lifestyle variables. These variables have been found to alter DNA transcription and, consequently, how genes are expressed. This process is referred to as epigenetics, which includes dynamic and adjustable molecular changes that reflect the body's interaction with its environment [6]. As a first step in addressing the obesity problem, we must understand the impact of lifestyle changes and therapeutic interventions on the epigenetic control of energy expenditure in obesity. In the current review, I will provide an overview of the intricate interplay between epigenetics and energy metabolism in the context of obesity development and management.

\section{The Role of Epigenetics in Obesity}

The significantly increased rate of obesity over the last few decades cannot be totally explained by genetics. Environmental variables such as nutrition and lifestyle may contribute to this tendency. These variables have the ability to change gene expression without affecting the DNA sequence, which is a phenomenon known as epigenetics. Conrad Waddington first introduced the concept of epigenetics in 1942, and it simply refers to chemical modifications that change how the body reads DNA. The most common epigenetic changes that have been thoroughly studied are DNA methylation, histone modifications, and non-coding RNAs [7].

Epigenetics has recently begun to provide explanations for alterations observed in many physiological and pathological processes, and the role of epigenetic modifications in obesity is becoming more apparent. One of the most common examples of epigenetics influence on obesity is the agouti mouse model. This model has a mutation in the agouti viable yellow (Avy) gene, which controls mouse coat color and is usually imprinted via DNA methylation. Aberrant hypomethylation of this gene causes ectopic expression of its protein, which binds to the melanocortin 4 receptor (MC4R) in the hypothalamus, disrupting its function and triggering hyperphagic obesity. Interestingly, this phenotype was attenuated in the offspring of mice fed a diet rich in methyl donors, indicating the reversibility of epigenetic alterations in response to external factors such as diet. Methyl donors are dietary components such as folate and methionine that provide methyl groups for biological DNA methylation. The diet-induced restoration of DNA methylation improved body weight and insulin sensitivity in the agouti mouse model, establishing the relationship between obesity and environmental-induced epigenetic changes [8].

Several genes implicated in obesity and other metabolic diseases are epigenetically regulated. This section will review current research, highlighting the contribution of major epigenetic alterations, mainly DNA methylation, histone modifications, and non-coding RNAs, to obesity.

\subsection{DNA Methylation}

DNA methylation is an essential epigenetic mechanism, and its role in the pathogenesis of several diseases has been extensively studied. The process of DNA methylation consists of covalent binding of a methyl group to a cytosine residue in the DNA, where cytosines are followed by guanines (CpG sites). This chemical modification is mediated via a group of enzymes called DNA methyltransferases (DNMTs). DNA methylation, especially in the gene promoter regions, interferes with gene transcription. This effect is achieved by preventing transcription factors from accessing the DNA and recruiting transcriptionrepressive proteins such as histone deacetylases (HDACs). Aberrant DNA methylation could occur at the global or specific gene level. For example, global DNA hypomethylation has been identified as a hallmark of several malignancies; however, a similar relationship in obesity is inconsistent among studies. Some studies observed global DNA hypomethylation in blood and adipose tissue samples from obese individuals [9], while others reported global hypermethylation [10]. 
Candidate gene methylation, on the other hand, exhibited more consistent findings. Leptin and adiponectin are at the top of the genes linked to obesity. These hormones are predominantly produced by the adipose tissue and regulate energy balance and metabolism. A recent study by Sadashiv et al. [11] reported a negative association between body weight and DNA methylation of the leptin $(L E P)$ gene promoter measured in blood in a cohort of obese adults. LEP promoter hypomethylation has also been linked to impaired glucose metabolism, decreased insulin sensitivity, and an altered lipid profile [11]. Similarly, in a cross-sectional study by Houde et al. [12], the body mass index of pre-bariatric obese adults correlated negatively with $L E P$ methylation and positively with adiponectin gene (ADIPOQ) methylation measured in subcutaneous adipose tissues. Several other investigations have confirmed the association between obesity and the methylation status of $L E P$ and $A D I P O Q$, which has been proposed to promote obesity-associated insulin resistance and metabolic derangements [13-15].

DNA methylation also regulates genes involved in insulin signaling, such as insulin (INS) [16], insulin receptor substrate 1 (IRS1) [17], and phosphatidylinositol 3-kinase regulatory subunit (PIK3R1) [18]. The methylation status of these genes was found to be altered under conditions of obesity and metabolic disease. For example, in a study by Rohde et al. [19], higher IRS1 promoter methylation and lower gene expression were observed in visceral and subcutaneous adipose tissues of a cohort of 146 obese individuals. In this study, IRS1 promoter methylation was directly associated with body weight, waist circumference, and indices of impaired glucose metabolism. It was also shown that DNA methylation of PIK3R1, an essential gene for insulin signaling, was reduced and its expression was enhanced after weight loss surgery [18]. A strong link was found between these methylation profiles and physiological outcomes such as insulin sensitivity and energy metabolism $[17,20]$.

Several other genes involved in the pathogenesis of obesity are regulated by DNA methylation. Of these are PGC1A (peroxisome proliferator-activated receptor $\gamma$ coactivator 1 alpha), a critical transcriptional factor for energy expenditure, and IGF-2 (insulin-like growth factor 2), which mediates vital cellular processes such as growth, differentiation, and metabolism. The methylation of these two genes was disrupted in obesity, gestational diabetes, and high-fat feeding but was restored in response to caloric restriction [21-23]. POMC (Pro-opiomelanocortin) and NPY (Neuropeptide Y) are two appetite-regulating genes whose methylation is altered in obesity; POMC promotes satiety, while NPY stimulates food intake. Weight gainers and individuals resistant to weight loss interventions had higher POMC methylation levels and lower NPY methylation levels [24].

Genes involved in hypoxia and inflammation are another example of altered DNA methylation in obesity. On top of these genes is HIF3A (hypoxia-inducible factor 3a), which is an essential gene in metabolic and physiological responses to hypoxia whose methylation has been linked to obesity in both adults and children $[25,26]$. In addition, genes involved in inflammation and oxidative stress such as TNF (tumor necrosis factor), IL6 (interleukin 6), and TFAM (mitochondrial transcription factor A) exhibited aberrant DNA methylation in obese individuals and correlated with abnormal expression and disturbed function of these genes [27-29]. Collectively, obesity has been linked to altered DNA methylation patterns, which could serve as biomarkers and therapeutic targets. These changes have been linked to a disrupted balance between DNA methyltransferases (DNMTs) and active demethylases such as TETs (Ten-eleven translocation methylcytosine dioxygenase 1) [28-31]. However, further research is needed to identify the underlying mechanisms of aberrant DNA methylation in obesity.

\subsection{Histone Modifications}

Histones are globular proteins around which DNA is wrapped to produce compact chromatin. There are five families of histones known as H1, H2A, H2B, H3, and H4. Post-translational modifications of these histones, including acetylation, methylation, phosphorylation, and ubiquitination, influence the compactness of DNA packing and hence 
the accessibility of transcription factors and subsequent gene expression. For example, histone acetylation stimulates gene expression by relaxing the DNA-histone interaction, rendering a permissible chromatin structure, whereas histone methylation can either activate or repress DNA transcription depending on the location and number of methylated residues [32]. Histone deacetylases (HDACs), histone acetyltransferases (HATs), histone demethylases (HDMs), and histone methyltransferases (HMTs) are among the enzymes responsible for histone modifications. Changes in these enzymes have been observed in obesity and linked to the altered expression of several genes involved in adiposity and metabolic functions [33]. HDACs and the histone 3 lysine 9 (H3K9)-specific demethylase, Jhdm2a, are at the top of the list of epigenetic modifiers that have been shown in clinical and mechanistic studies to accelerate the progression of obesity [34,35].

Histone modifications were shown to regulate the expression of critical genes in adipogenesis such as CCAAT enhancer-binding protein $\beta(C / E B P B), C / E B P A$, preadipocyte factor- 1 (Pref-1), adipocyte protein $2(a P 2)$, and peroxisome proliferator-activated receptor $\gamma(P P A R G)$ [36]. In addition to the DNA methylation discussed above, histone acetylation regulates the gene expression of the appetite-regulating genes POMC and NPY. Reduced acetylation of $\mathrm{H} 3 \mathrm{~K} 9$ at the $P M O C$ and increased acetylation of the same residue at the NPY gene have been associated with high-fat diet-induced obesity [37]. Increased acetylation of H3K9 and H3K18 at the TNF (tumor necrosis factor) and CCL2 (monocyte chemotactic protein 1) genes was also seen in the livers of high-fat diet-fed animals and is likely to be responsible for the induced inflammation [37]. On the other hand, caloric restriction and weight loss interventions reversed this pattern and elevated $\mathrm{H} 4$ acetylation and thus the expression of glucose transporter 4 (GLUT4) in adipose tissues [38]. These findings imply that histone alterations are involved in the epigenetic regulation of adipogenesis and may play a role in the development and progression of obesity.

\subsection{Non-Coding RNAs}

Non-coding RNAs are RNA molecules that are not translated into proteins but have a regulatory impact on gene expression. The most functionally relevant types of non-coding RNAs studied in the context of obesity are microRNAs (miRNAs) and long non-coding RNAs (lncRNAs). MicroRNAs are small molecules of RNA $(\approx 22$ nucleotides) that exert their function via post-transcriptional regulation of gene expression. Several miRNAs are involved in the process of adipogenesis, such as $m i R-30, m i R-26 b, m i R-199 a$, and $m i R-148 a$. These miRNAs were found in higher levels in obese individuals and mice fed a high-fat diet. Similarly, miR-17-5p and miR-132 were expressed at higher levels in the visceral adipose tissues of obese adults and correlated significantly with body mass index, glycosylated hemoglobin, and impaired glucose and lipid metabolism [39].

An induced expression of $m i R 21$ was found in the white adipose tissues of obese people compared to lean controls and correlated with impaired vascular function. Leptin-targeting miR221 was upregulated in obese people and diet-induced obese mice. In mechanistic models where these miRNAs were functionally silenced, reductions in the process of adipogenesis and triglyceride accumulation were observed, as well as improvements in body weight and metabolic function. A large number of miRNAs involved in adipogenesis, fat metabolism, insulin signaling, hypoxia, inflammation, and cell development and differentiation were discovered to be differently expressed in obese people. Landrier et al. [39] provide a comprehensive list of miRNAs related to obesity and metabolic diseases.

More research has recently begun to unravel the biological functions of lncRNAs, which are tissue-specific long RNA transcripts ( $>200 \mathrm{bp}$ ) that do not encode proteins but

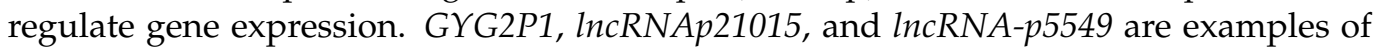
lncRNAs that are differentially expressed in obesity $[40,41]$. The expression level of these lncRNAs was reduced in obese individuals and correlated adversely with body mass index, waist circumference, fasting insulin, and triglycerides. RP11-20G13.3 is among the lncRNAs required to maintain PPAR, C/EBP, and $A D I P O Q$ levels during adipogenesis and is differentially expressed in obesity [40]. Other lncRNAs, such as lnc-dPrm16 and MIST, have 
been shown to influence brown adipogenesis, inflammation, and lipid metabolism [42,43]. Squillaro et al. [44] reported several other IncRNAs that contribute to obesity in a comprehensive review article, adding to the mounting evidence for the role of non-coding RNAs in obesity.

\section{Epigenetic Effects of Environmental Factors and Lifestyle}

Epigenetic mechanisms are dynamic and modifiable in response to environmental factors and lifestyle, allowing for adaptation to external stimuli and the restoration of standard epigenetic profiles when these stimuli are removed. The current section will discuss examples of environmental exposures, lifestyle factors, and therapeutic interventions that were shown to modify epigenetic mechanisms implicated in obesity.

\subsection{Obesogenic Exposures}

In 2002, Baillie-Hamilton et al. [45] brought to the scientific community's attention the fact that the start of the obesity epidemic coincided with the beginning of the industrial revolution and the use of several endocrine disruptors such as organophosphate pesticides, bisphenol A, solvents, chemicals, and heavy metals. Later on, Grun and Blumberg [46] developed the term "environmental obesogens," referring to environmental exposure to endocrine disruptors that induce adiposity via disrupting the body's natural mechanisms of weight control.

Bisphenol A (BPA), a synthetic compound present in beverage containers, water bottles, and dental materials, is one of the most widespread endocrine disruptors. Individuals with high plasma levels of BPA were more likely to develop visceral obesity, insulin resistance, and metabolic disorders [47]. Choi et al. [48] reported higher body mass index and differential methylation in the insulin growth factor 2 receptor (IGF2R) gene in children exposed to high BPA prenatally. Mechanistic studies in Agouti mice exposed to BPA revealed promoter hypomethylation and enhanced expression of the Agouti gene [8]. These mice were predisposed to obesity, diabetes, dyslipidemia, and other metabolic abnormalities. Furthermore, transient exposure to low doses of BPA altered global methylation, PPARG promoter methylation, and histone methylation (H3K4, H3K9, and H3K36) in cultured preadipocytes and other in vitro models [49-51].

Phthalates are chemical compounds used in plastic products such as medical devices and children's toys; they have endocrine-disrupting effects. A significant correlation was reported between urinary levels of phthalates and metabolic disorders, including obesity and insulin resistance. At the epigenetic level, phthalates were found to alter the methylation of metabolic genes such as PPARG, insulin growth factor 2 (IGF2), and sterol regulatory element-binding proteins (SREBPs) [52]. Furthermore, phthalates were found to stimulate the expression of $m i R-34 a-5 p$ while decreasing the expression of its target genes, nicotinamide phosphoribosyltransferase (NAMPT) and sirtuin 1 (Sirt1), both of which are essential for energy homeostasis [53]. The $\operatorname{lncRNAH19}$ and its downstream pathway related to insulin signaling were also altered in response to phthalates [54].

Organochlorine and organophosphate pesticides were found to accumulate in the adipose tissues and adversely affect metabolic pathways such as PPAR $\gamma$ and hepatic adenylyl cyclase/cyclic AMP signaling and inflammatory cytokines via mechanisms that involve global hypomethylation and aberrant histone methylation (H3K27) [55]. Growing epidemiological evidence supports the contribution of these pesticides to the global rise in obesity and diabetes [56]. Several other toxic environmental particles, industrial inhaled pollutants, and flame retardants were found to alter the DNA methylation status of PPARG and downstream pathways contributing to systemic inflammation and insulin resistance observed in obesity, diabetes, and other metabolic disorders.

\subsection{Dietary Factors}

Obesity is not simply the outcome of excess food intake or energy imbalance. Instead, numerous epigenetic mechanisms are implicated in diet-induced obesity. Association 
studies have linked specific dietary patterns with DNA methylation profiles in humans, as reported by Maugeri and Barchitta [57]. For example, a study by Piyathilake et al. [58] observed decreased global DNA methylation, as measured by the methylation level of long interspersed nucleotide element-1 (LINE-1) in the blood of women who consume high-fat meals versus those who follow healthy dietary patterns. A few clinical trials have further supported the link between high-fat diet consumption and DNA methylation. Brøns et al. [22] found that a five-day high-fat diet feeding increased DNA methylation of the transcription factor PPARG, which influences mitochondrial activity and energy metabolism. This impact was more pronounced in people with normal birth weight than those with low birth weight, who had higher PPARG methylation levels at baseline. The effect of a short-term high-fat diet was also observed in a genome-wide methylation analysis by Jacobsen et al. [59], who found alterations in DNA methylation in 6,508 genes implicated in inflammation, cancer, and reproduction in skeletal muscles of healthy young men.

Preclinical studies demonstrated that hypercaloric and high-fat diets modulate the methylation of genes involved in metabolism and appetite regulation, such as leptin (LEP) in the adipose tissues and melanocortin 4 receptor $(M C 4 R)$ in the brain [60]. Furthermore, elevated expression of the histone deacetylases HDAC5 and HDAC8 was observed in the ventromedial hypothalamus of rodents fed a high-fat diet, which subsequently dysregulated a myriad of genes responsible for energy metabolism and appetite regulation [34]. Chronic high-fat diet intake was also shown to induce HDAC9 that interfered with adipocyte differentiation, resulting in improperly differentiated adipocytes low in adiponectin and inefficient at storing lipids [61]. The epigenetic impact of a high-fat diet has been demonstrated to be mediated, at least partly, by HDAC11, which is a thermogenesis repressor gene that downregulates thermogenin/UCP1, PGC1A, and BRD2 (Bromodomaincontaining protein 2). HDAC11-deficient animals showed reduced body weight and fat mass and increased thermogenic capacity, metabolic rate, and physical activity when fed a high-fat diet compared to their wild-type counterparts [62].

The effects of a high-fat diet have been found to extend into the prenatal period. A high-fat maternal diet in rodents was shown to influence the hypothalamic regulation of energy metabolism and body weight in the offspring by causing epigenetic changes in the POMC, NPY, and LEPR genes. These changes were associated with the prevalence of obesity, dyslipidemia, steatohepatitis, insulin resistance, hyperglycemia, hyperleptinemia, and inflammation in the offspring, which lasted into adulthood [63]. A maternal highfat diet for four weeks in mice caused hypermethylation of the IRS2 (insulin receptor substrate 2) gene and hypomethylation of the MAP2K4 (mitogen-activated protein kinase 4) gene in the offspring. These modifications were associated with significant changes in IRS2 and MAP2K mRNA levels, as well as increased body weight, hyperglycemia, and insulin resistance [64]. The favorable epigenetic consequences of the prudent diet are supported by accumulating epidemiological evidence. For example, a cross-sectional study in Southern Italy by Zhang et al. found that consuming a balanced nutritious diet rich in fruits and vegetables was strongly associated with global DNA methylation in peripheral blood. Similar results were reported in the North Texas Healthy Heart Study [65].

Carbohydrates are a primary macronutrient in our diet that supply energy and hence can contribute to excessive energy consumption and weight gain. However, carbohydrates have a lower energy density than fat. When compared to low-fat diet trials, lowcarbohydrate diet studies showed mixed results in terms of weight loss and other health benefits. The reason behind this inconsistency is that our diets contain a wide variety of carbohydrates that have different glycemic indices and variable effects on our health. While sugar-sweetened beverage consumption has been associated to weight gain, dietary fibers and sugars from whole grains, fruits, and vegetables are significant sources of energy and are required for various physiological functions, including the microbiome [66].

Few studies have explored the influence of carbohydrate intake on inducing epigenetic changes that might alter the risk of obesity. For example, Lai et al. [67] reported a link between carbohydrate intake as well as the carbohydrate/fat ratio and a higher 
methylation status of CPT1 (Carnitine palmitoyltransferase-1) gene. CPT1 is involved in appetite regulation and insulin-mediated glucose and fatty acid metabolism, and its DNA methylation levels have been associated with a decreased risk of obesity. Similar results were seen in animal models fed a high-carbohydrate, low-fat diet, which increased CPT1 methylation in liver tissue and protected them from weight gain $[68,69]$. A study by Ramos-Lopez et al. [70] discovered a link between carbohydrate intake and the methylation state of the $D A$ (dopamine) gene, which codes for a neurotransmitter that regulates the central reward system and food intake. Hypermethylation and $D A$ downregulation have previously been connected to eating disorders and obesity indicators. Furthermore, DNA methylation of circadian clock genes such as RORA (RAR Related Orphan Receptor A) and $B M A L 1$ (brain and muscle aryl hydrocarbon receptor nuclear translocator-like 1), which control body metabolism, was found to be associated with carbohydrate consumption but not with protein or fat-rich diets. [71,72]. However, studies comparing the epigenetic impacts of various carbohydrate types are lacking. Furthermore, epigenetic alterations as a potential mechanism for the obesogenic effects of currently used sugar additives and artificial sweeteners need to be investigated.

Inadequate early nutrition, as seen in hypocaloric and low-protein diets, has also been linked to obesity, diabetes, hypertension, and hypercholesterolemia [73]. The Dutch famine in the winters of 1944 and 1945 is the best demonstration of this phenomenon [74]. These effects were reproduced in animal models, which aided our understanding of the epigenetic alterations responsible for the observed phenotypes. In these models, the offspring of mothers fed a hypocaloric, low-protein diet exhibited altered methylation of the hepatic PPARG and adrenal IGF2 genes and induced H4 acetylation of the GLUT4 and $C / E B P B$ genes. These changes appear to rewire orexigenic pathways and the brain's reward center, leading to binge eating, obesity, and metabolic abnormalities in the offspring $[75,76]$.

On the other hand, some micronutrients boost body metabolism and energy homeostasis by inducing favorable epigenetic alterations. Short-chain fatty acids (e.g., butyrate) and polyunsaturated fatty acids are examples of these nutrients, as they exert anti-inflammatory effects via modifying HDAC activity and DNA methylation [77]. During the one-carbon metabolism cycle, dietary methyl donors such as folate, methionine, choline, and betaine transfer a methyl group to the DNA and histones, contributing to epigenetic modifications and gene expression changes. Vitamins including $\mathrm{B}_{2}, \mathrm{~B}_{6}$, and $\mathrm{B}_{12}$ and minerals such as zinc and selenium are cofactors in the one-carbon cycle and contribute to epigenetic changes as well [78]. A cross-sectional study by Ramos-Lopez et al. [79] described an association between folate deficiency in obese subjects and hypomethylation of the CAMKK2 (calcium/calmodulin-dependent protein kinase 2) gene that regulates energy metabolism and insulin sensitivity. The insulin resistance index, HOMA-IR, correlated negatively with $C A M K K 2$ methylation and positively with its mRNA expression.

However, the direct correlation between folate and methyl donor consumption and global DNA methylation has not always been constant across investigations; some have observed inverse [80] or even null associations [20,81]. This discrepancy might be attributed to differences in participant characteristics across studies or inaccuracies in reporting food consumption. Some dietary nutrients, such as calcium, vitamin C, and vitamin E, have been demonstrated to promote epigenetic modifications that aid in weight regulation. In contrast, magnesium and chromium have been shown to induce alterations that predispose to obesity [82]. As a result, several of these micronutrients may be effective as epigenetic therapies. Nevertheless, further research is needed to understand their underlying mechanisms and the optimal doses considered to be protective.

The term "epigenetic diet" refers to bioactive nutritional compounds that can induce epigenetic changes and alter gene expression. This ever-expanding list of epigenetic nutrients includes minerals, vitamins, polyphenols, and various phytochemicals. Among these phytochemicals are resveratrol (grapes), tea catechins and polyphenols (green tea), genistein and quercetin (soybean), curcumin (turmeric), sulforaphane (cruciferous vegetables), and diallyl disulfide (garlic). However, most of the research to date has focused on 
the effect of these nutrients on cancer progression, and additional research is needed to determine a comparable protective role in obesity and metabolic diseases. Herein, I discuss a few examples of these phytochemicals reported to modulate body weight and energy expenditure via epigenetic mechanisms.

The tea catechin epigallocatechin-3-gallate (EGCG) has been shown to reduce body weight, blood glucose and insulin levels, liver triglycerides, cholesterol, and circulating inflammatory cytokines in rodent models. It was proposed that EGCG's ability to induce these effects was mediated by suppressing DNMT and histone acetyltransferase activity [83]. Another example of epigenetic micronutrients is dietary isoflavones. When administered at low doses, the soy isoflavone genistein enhanced body weight, lipid profile, and insulin sensitivity. This effect was mediated mainly by changes in the DNA methylation of multiple genes in the liver and muscles [82]. Curcumin, a turmeric polyphenol, has been shown in numerous studies to inhibit adipogenesis by increasing fatty acid oxidation and suppressing lipogenic and inflammatory gene expression. These effects were demonstrated to be mediated by changes in the activity of DNMTs, histone deacetylases and acetyltransferases, and many miRNAs [84].

Resveratrol, a well-known free radical scavenger that significantly improves cardiovascular and metabolic functioning, is a potent activator of the $(\mathrm{NAD}(+))$-dependent histone deacetylase, sirtuin 1 . Resveratrol has been proven in numerous studies to improve hepatic steatosis, insulin sensitivity, and raise the lipolysis/lipogenesis ratio, hence improving body weight in a manner comparable to caloric restriction diets [85]. Another example is the organosulfur compounds such as sulforaphane (cruciferous vegetables) and diallyl disulfide (garlic), which suppress adipogenesis and inflammation via modifying histone acetylation [86]. Overall, despite significant evidence for the anti-obesity benefits of these dietary components in animal models, there is a lack of intervention trials investigating their effects in humans.

\subsection{Physical Activity}

A sedentary lifestyle contributes to obesity via reducing insulin sensitivity, energy metabolism, mitochondrial function, and redox homeostasis. A growing body of research suggests that exercise can reverse these morbidities by triggering epigenetic modifications. Bajpeyi et al. [87] observed reductions in DNA methylation in the regulatory region of the $P G C 1 \alpha$ gene. This transcriptional factor regulates energy expenditure and mitochondrial biogenesis in skeletal muscle biopsies from exercising subjects. These findings were linked to enhanced $P G C 1 \alpha$ gene expression and lower intramyocellular lipid levels.

Genome-wide methylation analysis of adipose tissues after six months of endurance training demonstrated changes in the DNA methylation of 63 genes involved in obesity and diabetes, including KCNQ1 (potassium voltage-gated channel subfamily Q member 1), HHEX (haematopoietically expressed homeobox), IGF2BP2 (insulin-like growth factor 2 mRNA binding protein 2), JAZF1 (JAZF zinc finger 1), and TCF7L2 (transcription factor 7 like 2) [88]. Rowlands et al. [89] analyzed DNA methylation and miRNA expression in skeletal muscle biopsies obtained from sedentary obese and diabetic subjects before after 16 weeks of either aerobic or resistance training. Aerobic exercise decreased DNA methylation of NRF1 (nuclear respiratory factor 1), a transcription factor for essential metabolic genes, and increased the methylation of the FASN (fatty acid synthase) gene, resulting in improvements in metabolic functions and reductions in circulating lipids. The same intervention modified $m i R-29 a$ and $m i R-132$ that regulate genes involved in lipid and glucose metabolism and vascular function. Resistance training, on the other hand, modified metabolism-related miRNAs (i.e., $m i R-1207-5 p$ and $m i R-195$ ) and increased the methylation of SLC2A4 (solute carrier family 2), which is a gene that is important in fatty acid metabolism, mitochondrial function, and oxidative capacity. These modifications were associated with better glucose utilization and lower intramuscular lipids [89].

Several modes and intensities of exercise training have been demonstrated to be effective in restoring epigenetic patterns in humans. For example, 60 min of acute endurance 
exercise increased the expression of $m i R-1$ and $m i R-133 a$; both are critical for mitochondrial biogenesis [90]. Similarly, a single bout of acute exercise (10 $\mathrm{min}$ in total; $70-90 \%$ of maximum heart rate) increased several members of the $m i R-378$ family known to regulate the PGC1B gene, resulting in improvements in mitochondrial function, fatty acid oxidation, and insulin sensitivity [91]. Acute exercise training $(80 \%$ of maximum oxygen consumption $\left.\left(\mathrm{VO}_{2 \max }\right)\right)$ was also shown to decrease DNA methylation at the promotors of PGC1A, TFAM (transcription factor $\mathrm{A}$, mitochondrial), PPARD (peroxisome proliferator-activated receptor delta), $P D K 4$ (pyruvate dehydrogenase kinase 4), and CS (citrate synthase) genes. These genes play essential roles in mitochondrial activity, insulin sensitivity, and energy expenditure [92].

Short-term rehabilitation training (4 weeks) was found to alter the methylation of the AMPKA2 (PRKAA2; protein kinase AMP-activated catalytic subunit alpha 2) gene, which is a very important energy sensor that regulates fatty acid metabolism and insulin sensitivity [93]. In addition, short-term training ( 10 days at $75 \% \mathrm{VO}_{2 \max }$ ) effectively increased the expression of miR-133a, miR-133b, and miR-1 and reduced the level of miR-9, miR-23a, miR$23 b$, and $m i R-31$. These changes enhanced mitochondrial biogenesis, muscle growth, and metabolic adaptations in response to exercise training [94]. On the other hand, long-term endurance training (6 months) was shown to restore the DNA methylation profiles of genes involved in calcium signaling, glucose transporter 4 (GLUT4) translocation, and retinol metabolism in skeletal muscles [95]. In diabetic patients, 16 weeks of endurance traininginduced DNA hypomethylation in the PFKFB3 (6-phosphofructo-2-kinase/fructose-2,6biphosphatase 3), HDAC4 (histone deacetylase 4), and GSK3A (glycogen synthase kinase 3 alpha) genes responsible for glycolysis, transcriptional regulation, and glycogen synthesis, respectively [89]. According to a genome-wide methylation analysis, resistance training at $80 \%$ of the one-repetition maximum changed $57,384 \mathrm{CpG}$ sites in peripheral white blood cells. These locations have been assigned to genes involved in metabolic and calcium signaling pathways [96]. Several other studies summarized by Barrón-Cabrera et al. [97] have found that exercise training considerably promotes favorable epigenetic profiles that lower systemic inflammation and vascular remodeling in humans.

\subsection{Sleep Deprivation}

Recently, we began to recognize that factors other than eating more and exercising less may contribute to obesity. Previous research has described the impact of sleep disturbances and night shifting on the development of obesity, type 2 diabetes, and hypertension [98-100]. On the other hand, multiple studies have linked sleep deprivation to alterations in the epigenome, notably genes that influence circadian rhythm and are known to affect several metabolic functions [101,102]. Taken together, these findings suggest that sleep disturbances may trigger epigenetic changes that contribute to obesity and metabolic diseases. However, there has been a scarcity of research specifically investigating this triangular relationship.

The circadian rhythm is a translational-transcriptional feedback loop composed of positive transcriptional regulators such as CLOCK (circadian locomotor output cycles kaput) and BMAL1 (brain and muscle aryl hydrocarbon receptor nuclear translocator-like 1) and negative transcriptional regulators such as period 1, 2, and 3 (Per1, Per2, and Per3) and cryptochrome 1 and 2 (Cry1 and Cry2). This molecular clock machinery synchronizes the whole-body metabolism via regulating the expression of many genes, which are called clockcontrolled genes. The transcription of these genes has been shown to fluctuate in a circadian manner that is responsive to day/night cycles, diet, physical activity, and other lifestyle and environmental factors.

A single night of sleep deprivation was found to increase DNA methylation in the promoter of the Cry1 gene and the enhancer region of the Per1 gene in healthy men's adipose tissues. These findings were associated with decreased expression of the BMAL1 and Cry1 genes in skeletal muscles, as well as elevated blood cortisol levels and impaired glucose tolerance [103]. These observations were in line with prior findings by Zhu et al. [104], 
who reported CLOCK promoter hypomethylation and Cry2 hypermethylation in long-term night-shift workers. In addition to circadian genes, one-night sleep deprivation was found to induce promoter hypermethylation of SCD1 (Stearoyl-CoA Desaturase 1), a critical gene in lipid metabolism [105]. Furthermore, multiple studies have shown sleep deprivation to enhance the expression of the DNA methyltransferases DNMT3a1 and DNMT3a2, causing aberrant methylation of thousands of genes [106-108].

Changes in DNA methylation profiles in response to sleep deprivation were tissuespecific. For example, Cedernaes et al. [109] reported that acute sleep deprivation resulted in 148 differentially methylated regions (DMRs) in subcutaneous adipose tissue. Still, no significant DMRs were observed in skeletal muscle tissues in this study. The impact of sleep loss on DNA methylation was also gene-specific. Some genes exhibited DNA hypermethylation such as CD36 (fatty acid transporter), AKR1CL1 (Aldo-keto reductase family 1 member C8), and HOXA2 (homeobox A2), TRIM2 (tripartite motif-containing 2), and FOXP2 (forkhead box P2) genes involved in lipid metabolism, cell signaling, DNA repair, and adipogenesis. Other genes such as INS (insulin), GFI1 (growth factor independent 1 transcriptional repressor), CPT1A (carnitine palmitoyltransferase 1A), ADORA2A (adenosine A2a receptor) implicated in insulin signaling, lipolysis, metabolism, and fat beiging showed DNA hypomethylation.

Sleep deprivation has also been demonstrated to increase HDAC1/2 expression, resulting in decreased histone acetylation [110]. Indeed, the circadian rhythm genes CLOCK, $B M A L 1$, and Per1 are heavily regulated by rhythmic cycles of histone acetylation and deacetylation, in which HDAC1/2 and SIRT1 (sirtuin 1) play key roles [111]. In addition to disturbances in DNA methylation and histone acetylation, sleep loss induced $\operatorname{lncRNA}$ 116HG and A230107N01Rik, which were found to dysregulate circadian genes CLOCK, Cry1, and Per2 [112]. Furthermore, sleep deprivation was found to induce miR-192/194, miR-142-3p, miR-138, and miR-182, which modulate ADCY6 (adenylate cyclase 6) and the circadian genes, CLOCK, BMAL1, and Per1-3 [113-115]. These findings confirm the role of sleep deprivation in the development of obesity, most likely via disrupting the circadian clock genes.

\subsection{Alcohol Intake}

Several studies have linked excessive alcohol use to a higher BMI, explaining this by the fact that each gram of alcohol provides $7.1 \mathrm{Kcal}$ [116]. Aside from providing extra calories, alcohol has various epigenetic effects that may modify the risk of obesity. Ethanol has been found to disrupt the one-carbon metabolism cycle required for DNA methylation by inhibiting the enzyme methionine synthase and reducing the absorption of methyl donors such as folate and other B vitamins [117]. As a result, it is expected that excessive ethanol consumption will interfere with DNA methylation. Indeed, in prior research, my research group found a link between heavy alcohol consumption and DNA hypomethylation in peripheral blood as well as higher homocysteine levels in a cohort of morbidly obese individuals [118].

Acute alcohol intake was demonstrated to reduce global DNA methylation by inhibiting DNMTs. In contrast, chronic alcohol consumption resulted in apparent hypermethylation at global and gene-specific levels $[119,120]$. Examples of hypermethylated genes in response to chronic alcoholism are $P O M C$, which promotes satiety, and alpha-synuclein $(S N C A)$ that participates in glucose metabolism and insulin sensitivity in adipose tissues and skeletal muscles [121]. Several other genes involved in metabolism and the central reward center, including $B D N F$ (brain-derived neurotrophic factor), ALDH1L2 (aldehyde dehydrogenase), GABRP (GABA receptor), GAD1 (glutamate-decarboxylase), and $D B H$ (dopamine beta-hydroxylase), revealed abnormal DNA methylation in GWAS comparing alcoholics to non-alcoholics [122].

Alcohol has also been demonstrated to modify chromatin via changing histone methylation and acetylation. Chronic alcohol abuse resulted in global and gene-specific histone 3 methylation in the human cortex (H3K4me3) [123]. In animal models, chronic alco- 
hol consumption decreased the methylation/acetylation ratio of the H3K9 residue at the $N R 2 B$ (ionotropic glutamate receptor subunit) gene promoter, causing alterations in energy metabolism [124]. Furthermore, ethanol increased HDAC2 activity in the amygdala and altered histone acetylation at genes involved in appetite regulation, including CBP (sarcoplasmic calcium-binding protein) and NPY. Alcohol also altered the expression of numerous microRNAs implicated in the activity or reward center, alcohol dependence, and energy expenditure, such as $m i R-9, m i R-7$, and $m i R-134$ [122].

\subsection{Weight Loss Interventions}

Several epigenetic alterations were discovered in response to weight loss interventions. These changes are promising candidates for use as biomarkers that could distinguish responders from non-responders or help design unique weight loss strategies for each individual. On top of these alterations, promoter methylation of the inflammation-related gene, TNF (tumor necrosis factor), has lately gained attention as a possible biomarker of weight loss. Campión et al. [125] observed a dramatic reduction in TNF promoter methylation in the peripheral blood of subjects, who lost significant weight following eight weeks of a hypocaloric diet. Similar findings have been described by Cordero et al. [126], in which weight loss responders to a hypocaloric diet had reduced methylation of TNF and LEP genes in adipose tissues compared to non-responders.

DNA methylation array studies reported several differentially methylated genes among weight loss responders and non-responders. KCNA3 (potassium voltage-gated channel subfamily A member 3), INSM1 (insulinoma associated repression factor 1), NFIX (nuclear factor I X), ETS (V-ets avian erythroblastosis virus E26 oncogene homolog 1), and GLIS3 (GLIS family zinc finger 3) are examples of genes that were differentially methylated in responders' adipose tissues [127]. Similarly, the 18-month randomized controlled trial (CENTRAL) of the Mediterranean/low-carbohydrate or low-fat diet revealed substantial differences in DNA methylation between responders, who dropped more than $16 \%$ of their body weight, and non-responders. NUDT3 (nudix hydrolase 3), NCOR2 (nuclear receptor corepressor 2), $L R R C 27$ (leucine-rich repeat-containing 27), CRISP2 (cysteine-rich secretory protein 2), and SLFN12 (schlafen family member 12) genes, which regulate cell adhesion, metabolism, chromatin modification, and calcium signaling, were among those with significant changes in DNA methylation [128].

Circadian clock genes have recently been found to influence metabolic rhythmicity, and epigenetic changes may play a role in their regulation. Differences in the methylation of critical circadian genes such as CLOCK (clock circadian regulator), BMAL1 (aryl hydrocarbon receptor nuclear translocator-like), and PER2 (period circadian clock 2) were found in the blood of obese and non-obese people and after a 16-week weight loss program, implying the validity of epigenetic marks as weight loss biomarkers [129]. Moreover, research has revealed that DNA methylation of the appetite-regulation genes, POMC and $N P Y$, could serve as a biomarker of weight loss maintenance versus weight regain. Lower POMC methylation levels in the blood were connected to weight loss maintenance, but lower NPY methylation predicted weight rebound 32 weeks after a diet-based weight loss intervention [24]. Several studies have confirmed weight loss programs' potential to restore epigenetic alterations caused by an obesogenic diet and sedentary behavior. For example, following six weeks of an isocaloric balanced diet, alterations in DNA methylation that affected 6,508 genes in skeletal muscle were restored in humans [59]. Similarly, in animal models of high-fat diet-induced obesity, switching to a balanced chow diet restored standard methylation patterns of LEP promoters, SREBF1 (sterol regulatory element-binding transcription factor 1), PGC1A, and FASN [130].

Beyond diet and exercise trials, bariatric surgery is another weight loss strategy with long-term benefits such as enhanced insulin sensitivity, metabolism, and cardiovascular function. While changes in global DNA methylation varied between studies, there were consistent alterations in the DNA methylation of specific genes in muscle tissues such as PGC1 $\alpha, P D K 4$ (pyruvate dehydrogenase kinase 4), and SORBS3 (sorbin and SH3 do- 
main containing 3) after bariatric surgery [131,132]. These genes participate in metabolic pathways, cytoskeletal organization, cell adhesion, and cell signaling. DNA methylation changes after bariatric surgery were also identified in liver and adipose tissues for genes involved in insulin signaling and non-alcoholic fatty liver disease pathways [133,134]. In genome-wide analyses, after bariatric surgery, the differentially methylated regions (DMRs) were enriched in metabolic genes such as SCD (stearoyl CoA desaturase-1) that converts saturated fatty acids into monounsaturated fatty acids and has also been clinically linked to insulin sensitivity and circulating levels of free fatty acids and adiponectin [135]. These DMRs were also enriched in inflammation-related genes such as SERPINE-1 (serpin family E member 1), IL-6 (interleukin 6), TNF, IL-1B, and PKD4 [136]. In addition to DNA methylation, bariatric surgery has been shown to induce modification in miRNAs and lncRNAs that regulate the cell cycle, cell development, lipid metabolism, inflammatory response, insulin resistance, and endocrine function [137-139]. Overall, these findings suggest that weight loss is associated with the reversal of obesity epigenetic patterns and the acquisition of more favorable profiles associated with improved inflammatory, metabolic, and vascular function.

\subsection{Epigenetic Drugs}

In addition to being biomarkers of obesity progression and response to interventions, the epigenetic modifications discussed above serve as therapeutic targets for epigenetic modifiers. While these medications have long been approved for cancer treatment, their potential effects in restoring energy homeostasis and boosting metabolic function have only lately come to light. These drugs target histone deacetylases (HDACs) and demethylases (HDMs), DNA methyltransferases (DNMTs), and protein arginine methyltransferases (PRMTs). Among these drugs, HDAC inhibitors have received the most attention due to their effects on adipogenesis and insulin sensitivity. Valproic acid, a short-chain branched fatty acid with HDAC inhibitory action, was shown to modify hepatic gluconeogenesis and fatty acid oxidation, lowering blood glucose while improving hepatic lipid metabolism and reducing liver steatosis in obese mice [140], making valproic acid a good candidate for use as an adjuvant treatment in obesity and diabetes.

Sodium phenylbutyrate is another HDAC inhibitor that maintains cellular homeostasis by regulating protein folding, cell signaling, and endoplasmic reticulum stress. Although sodium phenylbutyrate did not reduce body weight in obese mice, it increased insulin and leptin sensitivity and decreased blood glucose, inflammation, and endoplasmic reticulum stress indicators [141]. Vorinostat and givinostat are orally active HDAC inhibitors that are effective in treating cancer but are currently being studied as a potential treatment for obesity and diabetes-related morbidities. Both inhibitors have been shown to reduce inflammation by suppressing inflammatory cytokines and transcriptional factors such as NFK $\beta$ (nuclear factor K B), IFN $\gamma$ (interferon-gamma), IL-1 $\beta$ (interleukin 1 beta), and TNF $\alpha$ (tumor necrosis factor-alpha) [142-144]. Givinostat increased pancreatic cell survival, glucose disposal, and insulin sensitivity and lowered inflammatory cytokines in a streptozotocin-induced diabetes mouse model, indicating its potential application in type 1 and type 2 diabetes [145].

Of the above-mentioned HDAC inhibitors, valproic acid and sodium phenylbutyrate have been tested in clinical trials for obesity and diabetes. In a clinical trial by Xiao et al. (NCT00533559; https:// clinicaltrials.gov/; accessed on 14 January 2022) [146], pretreatment with sodium phenylbutyrate protected subjects from $\beta$ cell dysfunction and insulin resistance following lipid infusion. Other clinical trials (NCT00771901; NCT00167934; NCT00298857; https: / / clinicaltrials.gov/; accessed on 14 January 2022) investigated the effect of sodium phenylbutyrate on insulin sensitivity in adipose tissues, skeletal muscles, and liver, body composition, lipid and glucose metabolism, fatty acid oxidation, endoplasmic reticulum stress indices, and inflammation [147].

Increased histone methylation has been linked to the pathophysiology and consequences of obesity, diabetes, and cardiovascular disease, and there is accumulating evi- 
dence that PRMTs play a role in this process [148]. For example, PRMT1 expression and its end product, asymmetrically dimethylated arginine (ADMA), have been linked to diabetic retinopathy and nephropathy in diabetic rats [149]. In addition, silencing PRMT1 restored euglycemic state in the leptin receptor-deficient diabetic mouse model [150]. Therefore, pharmacological inhibition of PRMT1 could alleviate diabetic complications. However, the development of PRMT inhibitors is slow, with only a few available inhibitors such as AMI-1 (7,7'-carbonylbis(azanediyl)bis(4-hydroxynaphthalene-2-sulfonic acid) [151].

Histone demethylation is another epigenetic pathway linked to the development of metabolic disorders. Histone demethylases (HDMs) such as lysine-specific demethylase 1 (LSD1) and LSD2 modulate energy expenditure and gluconeogenic enzymes, mainly G6Pase (glucose 6-phosphatase), FBP1 (fructose-1,6-bisphosphatase), and PEPCK (phosphoenolpyruvate carboxykinase) in adipose tissues [152,153]. Thus, histone demethylase inhibitors are emerging as treatments for obesity, diabetes, and associated comorbidities. Tranylcypromine is a histone demethylase inhibitor with significant adverse effects that have limited its usage to major depressive disorders. In animal models, pharmacological treatment with tranylcypromine inhibited LSDs and promoted the transcription of $F B P 1$, G6Pase, C/EBP, PPAR, PGC1, and PDK4 genes involved in gluconeogenesis and energy expenditure [152-154].

Several studies have reported the involvement of DNMTs in obesity and associated metabolic and cardiovascular consequences [6]. It has been postulated that methylation of the pancreatic homeobox transcription factor, PDX1, regulates pancreatic cell activity. In animal models, inducing DNMT1 activity reduced the expression of the PDX1 gene, resulting in hyperglycemia and disrupted metabolic function [155]. As a result, it was proposed that the pharmacological suppression of DNMT1 might be considered a viable therapy for obesity and diabetes in which DNMTs are upregulated. However, the use of DNMT inhibitors in treating these disorders is hampered by the significant side effects of the currently available medications. As an alternative, drugs with DNMT inhibitory activity that have been approved by the Food and Drug Administration (FDA) for other indications, such as the antihypertensive, antiarrhythmic medicines hydralazine and procainamide [156,157], are being investigated for their potential impact on treating obesity and diabetes (NCT00000620, NCT02046395; https:/ / clinicaltrials.gov/; accessed on 14 January 2022).

\section{Conclusions and Future Perspectives}

Epigenetics is a fast-expanding field of study, and the initial steps toward discovering possible biomarkers for obesity are already being taken. Overall, substantial progress has been achieved in understanding the role of epigenetics in translating the surrounding obesogenic environment to distinct functions and phenotypes (Figure 1). Yet, obesity is a complex, multifactorial disease characterized by an intricate interplay of numerous pathways linked to inflammation, metabolism, oxidative stress, hypoxia, and others. Therefore, there is still much to learn before we entirely comprehend the epigenome's role in obesity. To elucidate the epigenetic mechanisms that influence adipogenesis, glucose and lipid metabolism, insulin production, signaling, and appetite regulation, well-designed and controlled mechanistic and in vivo studies are required. These studies must explore the epigenetic consequences of hypoxia, inflammatory cytokines, reactive oxygen species, dyslipidemia, elevated glucose levels, hormonal imbalance, and endocrine disruptors. Furthermore, large, prospective research is required to determine whether changes in obesity risk variables, such as food, physical activity, sleeping patterns, alcohol consumption, and other environmental factors, are linked to changes in DNA methylation, chromatin modifications, or microRNA profiles. The modifiable nature of the epigenome should put it at the top of the list of therapeutic targets for obesity and its related comorbidities. Eventually, this may aid in anticipating an individual's obesity risk at an early stage, opening the door to implementing customized obesity prevention treatments. 


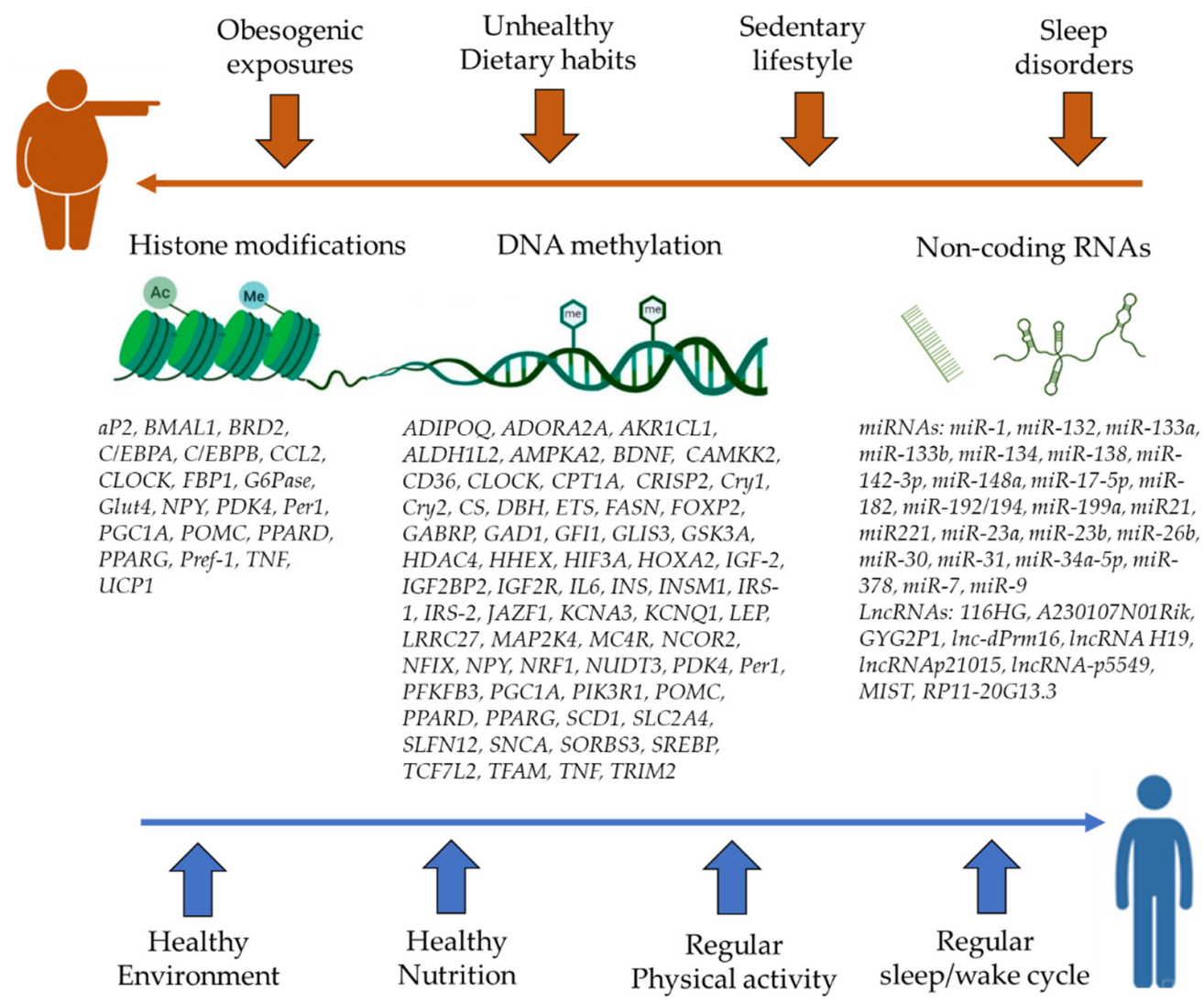

Figure 1. Epigenetic regulations of genes related to obesity. An illustration of the most prevalent epigenetic modifications and targeted genes researched in the context of obesogenic versus healthy lifestyle choices. ADIPOQ (adiponectin), ADORA2A (adenosine A2a receptor), AKR1CL1 (aldoketo reductase family 1 member C8), ALDH1L2 (aldehyde dehydrogenase 1 family member L2), AMPKA2 (AMP-activated, alpha 2 catalytic subunit), aP2 (adipocyte protein 2), BDNF (brain-derived neurotrophic factor), BMAL1 (brain and muscle aryl hydrocarbon receptor nuclear translocatorlike 1), BRD2 (bromodomain containing 2), C/EBPA (CCAAT enhancer binding protein alpha), $C / E B P B$ (CCAAT enhancer binding protein beta), CAMKK2 (calcium/calmodulin-dependent protein kinase kinase 2), CCL2 (C-C motif chemokine ligand 2), CLOCK (circadian locomotor output cycles kaput), CPT1A (carnitine palmitoyl transferase 1A), CRISP2 (cysteine rich secretory protein 2), Cry1 (cryptochrome circadian regulator 1), Cry2 (cryptochrome circadian regulator 2), CS (citrate synthase), $D B H$ (dopamine beta-hydroxylase), ETS (E-twenty-six transcription factor), FASN (fatty acid synthase), FBP1 (fructose-bisphosphatase 1), FOXP2 (forkhead box P2), G6Pase (glucose-6phosphatase), GABRP (gamma-aminobutyric acid type A receptor subunit pi), GAD1 (glutamate decarboxylase 1), GFI1 (growth factor independent 1 transcriptional repressor), GLIS3 (GLIS family zinc finger 3), GLUT4 (glucose transporter 4), GSK3A (glycogen synthase kinase 3 alpha), GYG2P1 (glycogenin 2 pseudogene 1), HDAC4 (histone deacetylase 4), HHEX (hematopoietically expressed homeobox), HIF3A (hypoxia-inducible factor 3 subunit alpha), HOXA2 (homeobox A2), IGF-2 (insulinlike growth factor 2), IGF2BP2 (insulin-like growth factor 2 mRNA-binding protein 2), IGF2R (insulinlike growth factor 2 receptor), IL6 (interleukin 6), INS (insulin), INSM1 (insulinoma-associated 1), IRS-1 (insulin receptor 1), IRS-2 (insulin receptor 2), JAZF1 (Juxtaposed with another zinc finger protein 1), KCNA3 (potassium voltage-gated channel subfamily A member 3), KCNQ1 (potassium voltage-gated channel subfamily Q member 1), LEP (leptin), LRRC27 (leucine-rich repeat containing 27), MAP2K4 (mitogen-activated protein kinase kinase 4), MC4R (melanocortin 4 receptor), MIST (Macrophage Inflammation-Suppressing Transcript), NCOR2 (nuclear receptor corepressor 2), NFIX 
(nuclear factor I X), NPY (neuropeptide Y), NRF1 (nuclear respiratory factor 1), NUDT3 (nudix hydrolase 3), PDK4 (pyruvate dehydrogenase kinase 4), Per1 (period circadian regulator 1), PFKFB3 (6phosphofructo-2-kinase/fructose-2,6-biphosphatase 3), PGC1A (PPARG coactivator 1 alpha), PIK3R1 (phosphoinositide-3-kinase regulatory subunit 1), POMC (proopiomelanocortin), PPARD (peroxisome proliferator-activated receptor delta), PPARG (peroxisome proliferator-activated receptor gamma), Pref-1 (DLK1; delta like non-canonical Notch ligand 1), SCD1 (stearoyl-coenzyme A desaturase 1), SLC2A4 (solute carrier family 2 member 4), SLFN12 (schlafen family member 12), SNCA (synuclein alpha), SORBS3 (sorbin and SH3 domain containing 3), SREBP (Sterol regulatory element binding protein), TCF7L2 (transcription factor 7 like 2), TFAM (transcription factor A, mitochondrial), TNF (tumor necrosis factor), TRIM2 (tripartite motif containing 2), UCP1 (uncoupling protein 1).

Funding: This research was funded by the NHLBI (National Heart, Lung, and Blood Institute) R00 HL140049-03 and R01HL161386-01 (AMM).

Institutional Review Board Statement: Not applicable.

Informed Consent Statement: Not applicable.

Data Availability Statement: Not applicable.

Conflicts of Interest: The author declares no conflict of interest.

\section{References}

1. Peeters, A.; Barendregt, J.J.; Willekens, F.; Mackenbach, J.P.; Al Mamun, A.; Bonneux, L. The Netherlands Epidemiology and Demography Compression of Morbidity Research Group. Obesity in adulthood and its consequences for life expectancy: A life-table analysis. Ann. Intern. Med. 2003, 138, 24-32. [CrossRef] [PubMed]

2. $\quad$ Pantalone, K.M.; Hobbs, T.M.; Chagin, K.M.; Kong, S.X.; Wells, B.J.; Kattan, M.W.; Bouchard, J.; Sakurada, B.; Milinovich, A.; Weng, W.; et al. Prevalence and recognition of obesity and its associated comorbidities: Cross-sectional analysis of electronic health record data from a large US integrated health system. BMJ Open 2017, 7, e017583. [CrossRef] [PubMed]

3. Gammone, M.A.; D'Orazio, N. COVID-19 and Obesity: Overlapping of Two Pandemics. Obes. Facts 2021, 14, 579-585. [CrossRef] [PubMed]

4. Yengo, L.; Sidorenko, J.; Kemper, K.E.; Zheng, Z.; Wood, A.R.; Weedon, M.N.; Frayling, T.M.; Hirschhorn, J.; Yang, J.; Visscher, P.M.; et al. Meta-analysis of genome-wide association studies for height and body mass index in approximately 700,000 individuals of European ancestry. Hum. Mol. Genet. 2018, 27, 3641-3649. [CrossRef]

5. Meldrum, D.R.; Morris, M.A.; Gambone, J.C. Obesity pandemic: Causes, consequences, and solutions-but do we have the will? Fertil. Steril. 2017, 107, 833-839. [CrossRef]

6. Park, Y.J.; Han, S.M.; Huh, J.Y.; Kim, J.B. Emerging roles of epigenetic regulation in obesity and metabolic disease. J. Biol. Chem. 2021, 297, 101296. [CrossRef]

7. Weinhold, B. Epigenetics: The science of change. Environ. Health Perspect. 2006, 114, A160-A167. [CrossRef]

8. Dolinoy, D.C. The agouti mouse model: An epigenetic biosensor for nutritional and environmental alterations on the fetal epigenome. Nutr. Rev. 2008, 66 (Suppl. 1), S7-S11. [CrossRef]

9. Turcot, V.; Tchernof, A.; Deshaies, Y.; Perusse, L.; Belisle, A.; Marceau, S.; Biron, S.; Lescelleur, O.; Biertho, L.; Vohl, M.C. LINE-1 methylation in visceral adipose tissue of severely obese individuals is associated with metabolic syndrome status and related phenotypes. Clin. Epigenet. 2012, 4, 10. [CrossRef]

10. Petrus, P.; Bialesova, L.; Checa, A.; Kerr, A.; Naz, S.; Backdahl, J.; Gracia, A.; Toft, S.; Dahlman-Wright, K.; Heden, P.; et al. Adipocyte Expression of SLC19A1 Links DNA Hypermethylation to Adipose Tissue Inflammation and Insulin Resistance. J. Clin. Endocrinol. Metab. 2018, 103, 710-721. [CrossRef]

11. Sadashiv; Modi, A.; Khokhar, M.; Sharma, P.; Joshi, R.; Mishra, S.S.; Bharshankar, R.N.; Tiwari, S.; Singh, P.K.; Bhosale, V.V.; et al. Leptin DNA Methylation and Its Association with Metabolic Risk Factors in a Northwest Indian Obese Population. J. Obes. Metab. Syndr. 2021, 30, 304-311. [CrossRef] [PubMed]

12. Houde, A.A.; Legare, C.; Biron, S.; Lescelleur, O.; Biertho, L.; Marceau, S.; Tchernof, A.; Vohl, M.C.; Hivert, M.F.; Bouchard, L. Leptin and adiponectin DNA methylation levels in adipose tissues and blood cells are associated with BMI, waist girth and LDL-cholesterol levels in severely obese men and women. BMC Med. Genet. 2015, 16, 29. [CrossRef] [PubMed]

13. Houshmand-Oeregaard, A.; Hansen, N.S.; Hjort, L.; Kelstrup, L.; Broholm, C.; Mathiesen, E.R.; Clausen, T.D.; Damm, P.; Vaag, A. Differential adipokine DNA methylation and gene expression in subcutaneous adipose tissue from adult offspring of women with diabetes in pregnancy. Clin. Epigenet. 2017, 9, 37. [CrossRef] [PubMed]

14. Ott, R.; Stupin, J.H.; Melchior, K.; Schellong, K.; Ziska, T.; Dudenhausen, J.W.; Henrich, W.; Rancourt, R.C.; Plagemann, A. Alterations of adiponectin gene expression and DNA methylation in adipose tissues and blood cells are associated with gestational diabetes and neonatal outcome. Clin. Epigenet. 2018, 10, 131. [CrossRef] [PubMed] 
15. Kim, A.Y.; Park, Y.J.; Pan, X.; Shin, K.C.; Kwak, S.H.; Bassas, A.F.; Sallam, R.M.; Park, K.S.; Alfadda, A.A.; Xu, A.; et al. Obesity-induced DNA hypermethylation of the adiponectin gene mediates insulin resistance. Nat. Commun. 2015, 6, 7585. [CrossRef]

16. Kuroda, A.; Rauch, T.A.; Todorov, I.; Ku, H.T.; Al-Abdullah, I.H.; Kandeel, F.; Mullen, Y.; Pfeifer, G.P.; Ferreri, K. Insulin gene expression is regulated by DNA methylation. PLoS ONE 2009, 4, e6953. [CrossRef]

17. Nilsson, E.; Jansson, P.A.; Perfilyev, A.; Volkov, P.; Pedersen, M.; Svensson, M.K.; Poulsen, P.; Ribel-Madsen, R.; Pedersen, N.L.; Almgren, P.; et al. Altered DNA methylation and differential expression of genes influencing metabolism and inflammation in adipose tissue from subjects with type 2 diabetes. Diabetes 2014, 63, 2962-2976. [CrossRef]

18. Pinhel, M.A.S.; Noronha, N.Y.; Nicoletti, C.F.; Pereira, V.A.; de Oliveira, B.A.; Cortes-Oliveira, C.; Salgado, W., Jr.; Barbosa, F., Jr.; Marchini, J.S.; Souza, D.R.; et al. Changes in DNA Methylation and Gene Expression of Insulin and Obesity-Related Gene PIK3R1 after Roux-en-Y Gastric Bypass. Int. J. Mol. Sci. 2020, 21, 4476. [CrossRef]

19. Rohde, K.; Klos, M.; Hopp, L.; Liu, X.; Keller, M.; Stumvoll, M.; Dietrich, A.; Schon, M.R.; Gartner, D.; Lohmann, T.; et al. IRS1 DNA promoter methylation and expression in human adipose tissue are related to fat distribution and metabolic traits. Sci. Rep. 2017, 7, 12369. [CrossRef]

20. Ahmed, S.A.H.; Ansari, S.A.; Mensah-Brown, E.P.K.; Emerald, B.S. The role of DNA methylation in the pathogenesis of type 2 diabetes mellitus. Clin. Epigenet. 2020, 12, 104. [CrossRef]

21. Gemma, C.; Sookoian, S.; Alvarinas, J.; Garcia, S.I.; Quintana, L.; Kanevsky, D.; Gonzalez, C.D.; Pirola, C.J. Maternal pregestational $\mathrm{BMI}$ is associated with methylation of the PPARGC1A promoter in newborns. Obesity 2009, 17, 1032-1039. [CrossRef] [PubMed]

22. Brons, C.; Jacobsen, S.; Nilsson, E.; Ronn, T.; Jensen, C.B.; Storgaard, H.; Poulsen, P.; Groop, L.; Ling, C.; Astrup, A.; et al. Deoxyribonucleic acid methylation and gene expression of PPARGC1A in human muscle is influenced by high-fat overfeeding in a birth-weight-dependent manner. J. Clin. Endocrinol. Metab. 2010, 95, 3048-3056. [CrossRef] [PubMed]

23. Perkins, E.; Murphy, S.K.; Murtha, A.P.; Schildkraut, J.; Jirtle, R.L.; Demark-Wahnefried, W.; Forman, M.R.; Kurtzberg, J.; Overcash, F.; Huang, Z.; et al. Insulin-like growth factor 2/H19 methylation at birth and risk of overweight and obesity in children. J. Pediatr. 2012, 161, 31-39. [CrossRef]

24. Crujeiras, A.B.; Campion, J.; Diaz-Lagares, A.; Milagro, F.I.; Goyenechea, E.; Abete, I.; Casanueva, F.F.; Martinez, J.A. Association of weight regain with specific methylation levels in the NPY and POMC promoters in leukocytes of obese men: A translational study. Regul. Pept. 2013, 186, 1-6. [CrossRef] [PubMed]

25. Dick, K.J.; Nelson, C.P.; Tsaprouni, L.; Sandling, J.K.; Aissi, D.; Wahl, S.; Meduri, E.; Morange, P.E.; Gagnon, F.; Grallert, H.; et al. DNA methylation and body-mass index: A genome-wide analysis. Lancet 2014, 383, 1990-1998. [CrossRef]

26. Pan, H.; Lin, X.; Wu, Y.; Chen, L.; Teh, A.L.; Soh, S.E.; Lee, Y.S.; Tint, M.T.; MacIsaac, J.L.; Morin, A.M.; et al. HIF3A association with adiposity: The story begins before birth. Epigenomics 2015, 7, 937-950. [CrossRef]

27. Na, Y.K.; Hong, H.S.; Lee, W.K.; Kim, Y.H.; Kim, D.S. Increased methylation of interleukin 6 gene is associated with obesity in Korean women. Mol. Cells 2015, 38, 452-456. [CrossRef]

28. Ali, M.M.; Naquiallah, D.; Qureshi, M.; Mirza, M.I.; Hassan, C.; Masrur, M.; Bianco, F.M.; Frederick, P.; Cristoforo, G.P.; Gangemi, A.; et al. DNA methylation profile of genes involved in inflammation and autoimmunity correlates with vascular function in morbidly obese adults. Epigenetics 2021, 25, 1-17. [CrossRef]

29. Ali, M.M.; Hassan, C.; Masrur, M.; Bianco, F.M.; Naquiallah, D.; Mirza, I.; Frederick, P.; Fernandes, E.T.; Giulianotti, C.P.; Gangemi, A.; et al. Adipose Tissue Hypoxia Correlates with Adipokine Hypomethylation and Vascular Dysfunction. Biomedicines 2021, 9, 1034. [CrossRef]

30. You, D.; Nilsson, E.; Tenen, D.E.; Lyubetskaya, A.; Lo, J.C.; Jiang, R.; Deng, J.; Dawes, B.A.; Vaag, A.; Ling, C.; et al. Dnmt3a is an epigenetic mediator of adipose insulin resistance. Elife 2017, 6, e30766. [CrossRef]

31. Ma, X.; Kang, S. Functional Implications of DNA Methylation in Adipose Biology. Diabetes 2019, 68, 871-878. [CrossRef] [PubMed]

32. Castillo, J.; Lopez-Rodas, G.; Franco, L. Histone Post-Translational Modifications and Nucleosome Organisation in Transcriptional Regulation: Some Open Questions. Adv. Exp. Med. Biol. 2017, 966, 65-92. [CrossRef] [PubMed]

33. Yang, H.; Yang, K.; Gu, H.; Sun, C. Dynamic post-translational modifications in obesity. J. Cell Mol. Med. 2020, $24,2384-2387$. [CrossRef] [PubMed]

34. Funato, H.; Oda, S.; Yokofujita, J.; Igarashi, H.; Kuroda, M. Fasting and high-fat diet alter histone deacetylase expression in the medial hypothalamus. PLoS ONE 2011, 6, e18950. [CrossRef] [PubMed]

35. Tateishi, K.; Okada, Y.; Kallin, E.M.; Zhang, Y. Role of Jhdm2a in regulating metabolic gene expression and obesity resistance. Nature 2009, 458, 757-761. [CrossRef] [PubMed]

36. Zhang, Q.; Ramlee, M.K.; Brunmeir, R.; Villanueva, C.J.; Halperin, D.; Xu, F. Dynamic and distinct histone modifications modulate the expression of key adipogenesis regulatory genes. Cell Cycle 2012, 11, 4310-4322. [CrossRef] [PubMed]

37. Mikula, M.; Majewska, A.; Ledwon, J.K.; Dzwonek, A.; Ostrowski, J. Obesity increases histone H3 lysine 9 and 18 acetylation at Tnfa and Ccl2 genes in mouse liver. Int. J. Mol. Med. 2014, 34, 1647-1654. [CrossRef]

38. Wheatley, K.E.; Nogueira, L.M.; Perkins, S.N.; Hursting, S.D. Differential effects of calorie restriction and exercise on the adipose transcriptome in diet-induced obese mice. J. Obes. 2011, 2011, 265417. [CrossRef]

39. Landrier, J.F.; Derghal, A.; Mounien, L. MicroRNAs in Obesity and Related Metabolic Disorders. Cells 2019, 8, 859. [CrossRef]

40. Liu, Y.; Ji, Y.; Li, M.; Wang, M.; Yi, X.; Yin, C.; Wang, S.; Zhang, M.; Zhao, Z.; Xiao, Y. Integrated analysis of long noncoding RNA and mRNA expression profile in children with obesity by microarray analysis. Sci. Rep. 2018, 8, 8750. [CrossRef] 
41. Sun, J.; Ruan, Y.; Wang, M.; Chen, R.; Yu, N.; Sun, L.; Liu, T.; Chen, H. Differentially expressed circulating LncRNAs and mRNA identified by microarray analysis in obese patients. Sci. Rep. 2016, 6, 35421. [CrossRef] [PubMed]

42. Ding, C.; Lim, Y.C.; Chia, S.Y.; Walet, A.C.E.; Xu, S.; Lo, K.A.; Zhao, Y.; Zhu, D.; Shan, Z.; Chen, Q.; et al. De novo reconstruction of human adipose transcriptome reveals conserved lncRNAs as regulators of brown adipogenesis. Nat. Commun. 2018, 9, 1329. [CrossRef] [PubMed]

43. Stapleton, K.; Das, S.; Reddy, M.A.; Leung, A.; Amaram, V.; Lanting, L.; Chen, Z.; Zhang, L.; Palanivel, R.; Deiuliis, J.A.; et al. Novel Long Noncoding RNA, Macrophage Inflammation-Suppressing Transcript (MIST), Regulates Macrophage Activation During Obesity. Arterioscler. Thromb. Vasc. Biol. 2020, 40, 914-928. [CrossRef] [PubMed]

44. Squillaro, T.; Peluso, G.; Galderisi, U.; Di Bernardo, G. Long non-coding RNAs in regulation of adipogenesis and adipose tissue function. Elife 2020, 9, e59053. [CrossRef]

45. Baillie-Hamilton, P.F. Chemical toxins: A hypothesis to explain the global obesity epidemic. J. Altern. Complement. Med. 2002, 8 , 185-192. [CrossRef]

46. Grun, F.; Blumberg, B. Environmental obesogens: Organotins and endocrine disruption via nuclear receptor signaling. Endocrinology 2006, 147, S50-S55. [CrossRef] [PubMed]

47. Savastano, S.; Tarantino, G.; D’Esposito, V.; Passaretti, F.; Cabaro, S.; Liotti, A.; Liguoro, D.; Perruolo, G.; Ariemma, F.; Finelli, C.; et al. Bisphenol-A plasma levels are related to inflammatory markers, visceral obesity and insulin-resistance: A cross-sectional study on adult male population. J. Transl. Med. 2015, 13, 169. [CrossRef]

48. Choi, Y.J.; Lee, Y.A.; Hong, Y.C.; Cho, J.; Lee, K.S.; Shin, C.H.; Kim, B.N.; Kim, J.I.; Park, S.J.; Bisgaard, H.; et al. Effect of prenatal bisphenol A exposure on early childhood body mass index through epigenetic influence on the insulin-like growth factor 2 receptor (IGF2R) gene. Environ. Int. 2020, 143, 105929. [CrossRef]

49. Bastos Sales, L.; Kamstra, J.H.; Cenijn, P.H.; van Rijt, L.S.; Hamers, T.; Legler, J. Effects of endocrine disrupting chemicals on in vitro global DNA methylation and adipocyte differentiation. Toxicol. Vitr. 2013, 27, 1634-1643. [CrossRef]

50. Chevalier, N.; Fenichel, P. Endocrine disruptors: New players in the pathophysiology of type 2 diabetes? Diabetes Metab. 2015, 41, 107-115. [CrossRef]

51. Strakovsky, R.S.; Wang, H.; Engeseth, N.J.; Flaws, J.A.; Helferich, W.G.; Pan, Y.X.; Lezmi, S. Developmental bisphenol A (BPA) exposure leads to sex-specific modification of hepatic gene expression and epigenome at birth that may exacerbate high-fat diet-induced hepatic steatosis. Toxicol. Appl. Pharmacol. 2015, 284, 101-112. [CrossRef] [PubMed]

52. Dutta, S.; Haggerty, D.K.; Rappolee, D.A.; Ruden, D.M. Phthalate Exposure and Long-Term Epigenomic Consequences: A Review. Front. Genet. 2020, 11, 405. [CrossRef]

53. Meruvu, S.; Zhang, J.; Choudhury, M. Butyl Benzyl Phthalate Promotes Adipogenesis in 3T3-L1 Cells via the miRNA-34a-5p Signaling Pathway in the Absence of Exogenous Adipogenic Stimuli. Chem. Res. Toxicol. 2021, 34, 2251-2260. [CrossRef] [PubMed]

54. Zhang, J.; Choudhury, M. Benzyl Butyl Phthalate Induced Early lncRNA H19 Regulation in C3H10T1/2 Stem Cell Line. Chem. Res. Toxicol. 2021, 34, 54-62. [CrossRef]

55. Janesick, A.; Blumberg, B. Minireview: PPARgamma as the target of obesogens. J. Steroid Biochem. Mol. Biol. 2011, 127, 4-8. [CrossRef]

56. Slotkin, T.A. Does early-life exposure to organophosphate insecticides lead to prediabetes and obesity? Reprod. Toxicol. 2011, 31, 297-301. [CrossRef] [PubMed]

57. Maugeri, A.; Barchitta, M. How Dietary Factors Affect DNA Methylation: Lesson from Epidemiological Studies. Medicina 2020, 56, 374. [CrossRef]

58. Piyathilake, C.J.; Badiga, S.; Kabagambe, E.K.; Azuero, A.; Alvarez, R.D.; Johanning, G.L.; Partridge, E.E. A dietary pattern associated with LINE-1 methylation alters the risk of developing cervical intraepithelial neoplasia. Cancer Prev. Res. 2012, 5 , 385-392. [CrossRef]

59. Jacobsen, S.C.; Brons, C.; Bork-Jensen, J.; Ribel-Madsen, R.; Yang, B.; Lara, E.; Hall, E.; Calvanese, V.; Nilsson, E.; Jorgensen, S.W.; et al. Effects of short-term high-fat overfeeding on genome-wide DNA methylation in the skeletal muscle of healthy young men. Diabetologia 2012, 55, 3341-3349. [CrossRef]

60. Widiker, S.; Karst, S.; Wagener, A.; Brockmann, G.A. High-fat diet leads to a decreased methylation of the Mc4r gene in the obese BFMI and the lean B6 mouse lines. J. Appl. Genet. 2010, 51, 193-197. [CrossRef] [PubMed]

61. Chatterjee, T.K.; Basford, J.E.; Yiew, K.H.; Stepp, D.W.; Hui, D.Y.; Weintraub, N.L. Role of histone deacetylase 9 in regulating adipogenic differentiation and high fat diet-induced metabolic disease. Adipocyte 2014, 3, 333-338. [CrossRef] [PubMed]

62. Bagchi, R.A.; Ferguson, B.S.; Stratton, M.S.; Hu, T.; Cavasin, M.A.; Sun, L.; Lin, Y.H.; Liu, D.; Londono, P.; Song, K.; et al. HDAC11 suppresses the thermogenic program of adipose tissue via BRD2. JCI Insight 2018, 3, e120159. [CrossRef] [PubMed]

63. Couvreur, O.; Ferezou, J.; Gripois, D.; Serougne, C.; Crepin, D.; Aubourg, A.; Gertler, A.; Vacher, C.M.; Taouis, M. Unexpected long-term protection of adult offspring born to high-fat fed dams against obesity induced by a sucrose-rich diet. PLOS ONE 2011, 6, e18043. [CrossRef] [PubMed]

64. Zhang, Q.; Xiao, X.; Zheng, J.; Li, M.; Yu, M.; Ping, F.; Wang, T.; Wang, X. A Maternal High-Fat Diet Induces DNA Methylation Changes That Contribute to Glucose Intolerance in Offspring. Front. Endocrinol. 2019, 10, 871. [CrossRef] [PubMed] 
65. Zhang, F.F.; Morabia, A.; Carroll, J.; Gonzalez, K.; Fulda, K.; Kaur, M.; Vishwanatha, J.K.; Santella, R.M.; Cardarelli, R. Dietary patterns are associated with levels of global genomic DNA methylation in a cancer-free population. J. Nutr. 2011, 141, 1165-1171. [CrossRef] [PubMed]

66. van Dam, R.M.; Seidell, J.C. Carbohydrate intake and obesity. Eur. J. Clin. Nutr. 2007, 61 (Suppl. 1), S75-S99. [CrossRef] [PubMed]

67. Lai, C.Q.; Parnell, L.D.; Smith, C.E.; Guo, T.; Sayols-Baixeras, S.; Aslibekyan, S.; Tiwari, H.K.; Irvin, M.R.; Bender, C.; Fei, D.; et al. Carbohydrate and fat intake associated with risk of metabolic diseases through epigenetics of CPT1A. Am. J. Clin. Nutr. 2020, 112, 1200-1211. [CrossRef]

68. Moody, L.; Xu, G.B.; Chen, H.; Pan, Y.X. Epigenetic regulation of carnitine palmitoyltransferase 1 (Cpt1a) by high fat diet. Biochim. Biophys. Acta Gene Regul. Mech. 2019, 1862, 141-152. [CrossRef]

69. Ohashi, K.; Munetsuna, E.; Yamada, H.; Ando, Y.; Yamazaki, M.; Taromaru, N.; Nagura, A.; Ishikawa, H.; Suzuki, K.; Teradaira, R.; et al. High fructose consumption induces DNA methylation at PPARalpha and CPT1A promoter regions in the rat liver. Biochem. Biophys. Res. Commun. 2015, 468, 185-189. [CrossRef]

70. Ramos-Lopez, O.; Riezu-Boj, J.I.; Milagro, F.I.; Martinez, J.A.; Project, M. Dopamine gene methylation patterns are associated with obesity markers and carbohydrate intake. Brain Behav. 2018, 8, e01017. [CrossRef]

71. Samblas, M.; Milagro, F.I.; Gomez-Abellan, P.; Martinez, J.A.; Garaulet, M. Methylation on the Circadian Gene BMAL1 Is Associated with the Effects of a Weight Loss Intervention on Serum Lipid Levels. J. Biol. Rhythms. 2016, 31, 308-317. [CrossRef] [PubMed]

72. Ramos-Lopez, O.; Samblas, M.; Milagro, F.I.; Riezu-Boj, J.I.; Crujeiras, A.B.; Martinez, J.A.; Project, M. Circadian gene methylation profiles are associated with obesity, metabolic disturbances and carbohydrate intake. Chronobiol. Int. 2018, 35, 969-981. [CrossRef] [PubMed]

73. Martin-Gronert, M.S.; Ozanne, S.E. Mechanisms linking suboptimal early nutrition and increased risk of type 2 diabetes and obesity. J. Nutr. 2010, 140, 662-666. [CrossRef] [PubMed]

74. Heijmans, B.T.; Tobi, E.W.; Stein, A.D.; Putter, H.; Blauw, G.J.; Susser, E.S.; Slagboom, P.E.; Lumey, L.H. Persistent epigenetic differences associated with prenatal exposure to famine in humans. Proc. Natl. Acad. Sci. USA 2008, 105, 17046-17049. [CrossRef]

75. Zheng, S.; Rollet, M.; Pan, Y.X. Maternal protein restriction during pregnancy induces CCAAT/enhancer-binding protein (C/EBPbeta) expression through the regulation of histone modification at its promoter region in female offspring rat skeletal muscle. Epigenetics 2011, 6, 161-170. [CrossRef]

76. Sohi, G.; Marchand, K.; Revesz, A.; Arany, E.; Hardy, D.B. Maternal protein restriction elevates cholesterol in adult rat offspring due to repressive changes in histone modifications at the cholesterol 7alpha-hydroxylase promoter. Mol. Endocrinol. 2011, 25, 785-798. [CrossRef]

77. Calder, P.C.; Ahluwalia, N.; Brouns, F.; Buetler, T.; Clement, K.; Cunningham, K.; Esposito, K.; Jonsson, L.S.; Kolb, H.; Lansink, M.; et al. Dietary factors and low-grade inflammation in relation to overweight and obesity. Br. J. Nutr. 2011, 106 (Suppl. 3), S5-S78. [CrossRef]

78. Zeisel, S.H. Epigenetic mechanisms for nutrition determinants of later health outcomes. Am. J. Clin. Nutr. 2009, 89, 1488S-1493S. [CrossRef]

79. Ramos-Lopez, O.; Samblas, M.; Milagro, F.I.; Zulet, M.A.; Mansego, M.L.; Riezu-Boj, J.I.; Martinez, J.A. Association of low dietary folate intake with lower CAMKK2 gene methylation, adiposity, and insulin resistance in obese subjects. Nutr. Res. 2018, 50, 53-62. [CrossRef]

80. Ono, H.; Iwasaki, M.; Kuchiba, A.; Kasuga, Y.; Yokoyama, S.; Onuma, H.; Nishimura, H.; Kusama, R.; Ohnami, S.; Sakamoto, H.; et al. Association of dietary and genetic factors related to one-carbon metabolism with global methylation level of leukocyte DNA. Cancer Sci. 2012, 103, 2159-2164. [CrossRef]

81. Zhang, F.F.; Cardarelli, R.; Carroll, J.; Fulda, K.G.; Kaur, M.; Gonzalez, K.; Vishwanatha, J.K.; Santella, R.M.; Morabia, A. Significant differences in global genomic DNA methylation by gender and race/ethnicity in peripheral blood. Epigenetics 2011, 6, 623-629. [CrossRef] [PubMed]

82. Milagro, F.I.; Mansego, M.L.; De Miguel, C.; Martinez, J.A. Dietary factors, epigenetic modifications and obesity outcomes: Progresses and perspectives. Mol. Aspects Med. 2013, 34, 782-812. [CrossRef] [PubMed]

83. Chen, Y.K.; Cheung, C.; Reuhl, K.R.; Liu, A.B.; Lee, M.J.; Lu, Y.P.; Yang, C.S. Effects of green tea polyphenol (-)-epigallocatechin-3gallate on newly developed high-fat/Western-style diet-induced obesity and metabolic syndrome in mice. J. Agric. Food Chem. 2011, 59, 11862-11871. [CrossRef] [PubMed]

84. Shao, W.; Yu, Z.; Chiang, Y.; Yang, Y.; Chai, T.; Foltz, W.; Lu, H.; Fantus, I.G.; Jin, T. Curcumin prevents high fat diet induced insulin resistance and obesity via attenuating lipogenesis in liver and inflammatory pathway in adipocytes. PLoS ONE 2012, 7, e28784. [CrossRef]

85. Camins, A.; Sureda, F.X.; Junyent, F.; Verdaguer, E.; Folch, J.; Pelegri, C.; Vilaplana, J.; Beas-Zarate, C.; Pallas, M. Sirtuin activators: Designing molecules to extend life span. Biochim. Biophys. Acta 2010, 1799, 740-749. [CrossRef]

86. Choi, S.W.; Friso, S. Epigenetics: A New Bridge between Nutrition and Health. Adv. Nutr. 2010, 1, 8-16. [CrossRef]

87. Bajpeyi, S.; Covington, J.D.; Taylor, E.M.; Stewart, L.K.; Galgani, J.E.; Henagan, T.M. Skeletal Muscle PGC1alpha -1 Nucleosome Position and -260 nt DNA Methylation Determine Exercise Response and Prevent Ectopic Lipid Accumulation in Men. Endocrinology 2017, 158, 2190-2199. [CrossRef] 
88. Ronn, T.; Volkov, P.; Davegardh, C.; Dayeh, T.; Hall, E.; Olsson, A.H.; Nilsson, E.; Tornberg, A.; Dekker Nitert, M.; Eriksson, K.F.; et al. A six months exercise intervention influences the genome-wide DNA methylation pattern in human adipose tissue. PLoS Genet. 2013, 9, e1003572. [CrossRef]

89. Rowlands, D.S.; Page, R.A.; Sukala, W.R.; Giri, M.; Ghimbovschi, S.D.; Hayat, I.; Cheema, B.S.; Lys, I.; Leikis, M.; Sheard, P.W.; et al. Multi-omic integrated networks connect DNA methylation and miRNA with skeletal muscle plasticity to chronic exercise in Type 2 diabetic obesity. Physiol. Genomics 2014, 46, 747-765. [CrossRef]

90. Nielsen, S.; Scheele, C.; Yfanti, C.; Akerstrom, T.; Nielsen, A.R.; Pedersen, B.K.; Laye, M.J. Muscle specific microRNAs are regulated by endurance exercise in human skeletal muscle. J. Physiol. 2010, 588, 4029-4037. [CrossRef]

91. McLean, C.S.; Mielke, C.; Cordova, J.M.; Langlais, P.R.; Bowen, B.; Miranda, D.; Coletta, D.K.; Mandarino, L.J. Gene and MicroRNA Expression Responses to Exercise; Relationship with Insulin Sensitivity. PLoS ONE 2015, 10, e0127089. [CrossRef] [PubMed]

92. Barres, R.; Yan, J.; Egan, B.; Treebak, J.T.; Rasmussen, M.; Fritz, T.; Caidahl, K.; Krook, A.; O'Gorman, D.J.; Zierath, J.R. Acute exercise remodels promoter methylation in human skeletal muscle. Cell Metab. 2012, 15, 405-411. [CrossRef] [PubMed]

93. King-Himmelreich, T.S.; Schramm, S.; Wolters, M.C.; Schmetzer, J.; Moser, C.V.; Knothe, C.; Resch, E.; Peil, J.; Geisslinger, G.; Niederberger, E. The impact of endurance exercise on global and AMPK gene-specific DNA methylation. Biochem. Biophys. Res. Commun. 2016, 474, 284-290. [CrossRef] [PubMed]

94. Russell, A.P.; Lamon, S.; Boon, H.; Wada, S.; Guller, I.; Brown, E.L.; Chibalin, A.V.; Zierath, J.R.; Snow, R.J.; Stepto, N.; et al. Regulation of miRNAs in human skeletal muscle following acute endurance exercise and short-term endurance training. J. Physiol. 2013, 591, 4637-4653. [CrossRef]

95. Nitert, M.D.; Dayeh, T.; Volkov, P.; Elgzyri, T.; Hall, E.; Nilsson, E.; Yang, B.T.; Lang, S.; Parikh, H.; Wessman, Y.; et al. Impact of an exercise intervention on DNA methylation in skeletal muscle from first-degree relatives of patients with type 2 diabetes. Diabetes 2012, 61, 3322-3332. [CrossRef] [PubMed]

96. Denham, J.; Marques, F.Z.; Bruns, E.L.; O'Brien, B.J.; Charchar, F.J. Epigenetic changes in leukocytes after 8 weeks of resistance exercise training. Eur. J. Appl. Physiol. 2016, 116, 1245-1253. [CrossRef] [PubMed]

97. Barron-Cabrera, E.; Ramos-Lopez, O.; Gonzalez-Becerra, K.; Riezu-Boj, J.I.; Milagro, F.I.; Martinez-Lopez, E.; Martinez, J.A. Epigenetic Modifications as Outcomes of Exercise Interventions Related to Specific Metabolic Alterations: A Systematic Review. Lifestyle Genom. 2019, 12, 25-44. [CrossRef]

98. Calhoun, D.A.; Harding, S.M. Sleep and hypertension. Chest 2010, 138, 434-443. [CrossRef]

99. Al-Abri, M.A.; Jaju, D.; Al-Sinani, S.; Al-Mamari, A.; Albarwani, S.; Al-Resadi, K.; Bayoumi, R.; Hassan, M.; Al-Hashmi, K Habitual Sleep Deprivation is Associated with Type 2 Diabetes: A Case-Control Study. Oman Med. J. 2016, 31, 399-403. [CrossRef]

100. Cooper, C.B.; Neufeld, E.V.; Dolezal, B.A.; Martin, J.L. Sleep deprivation and obesity in adults: A brief narrative review. BMJ Open Sport Exerc. Med. 2018, 4, e000392. [CrossRef]

101. Gaine, M.E.; Chatterjee, S.; Abel, T. Sleep Deprivation and the Epigenome. Front. Neural Circuits 2018, 12, 14. [CrossRef] [PubMed]

102. Cortese, R. Epigenetics of Sleep Disorders: An Emerging Field in Diagnosis and Therapeutics. Diagnostics 2021, 11, 851. [CrossRef] [PubMed]

103. Cedernaes, J.; Osler, M.E.; Voisin, S.; Broman, J.E.; Vogel, H.; Dickson, S.L.; Zierath, J.R.; Schioth, H.B.; Benedict, C. Acute Sleep Loss Induces Tissue-Specific Epigenetic and Transcriptional Alterations to Circadian Clock Genes in Men. J. Clin. Endocrinol. Metab. 2015, 100, E1255-E1261. [CrossRef] [PubMed]

104. Zhu, Y.; Stevens, R.G.; Hoffman, A.E.; Tjonneland, A.; Vogel, U.B.; Zheng, T.; Hansen, J. Epigenetic impact of long-term shiftwork: Pilot evidence from circadian genes and whole-genome methylation analysis. Chronobiol. Int. 2011, 28, 852-861. [CrossRef] [PubMed]

105. Skuladottir, G.V.; Nilsson, E.K.; Mwinyi, J.; Schioth, H.B. One-night sleep deprivation induces changes in the DNA methylation and serum activity indices of stearoyl-CoA desaturase in young healthy men. Lipids Health Dis. 2016, 15, 137. [CrossRef] [PubMed]

106. Wong, C.C.; Parsons, M.J.; Lester, K.J.; Burrage, J.; Eley, T.C.; Mill, J.; Dempster, E.L.; Gregory, A.M. Epigenome-Wide DNA Methylation Analysis of Monozygotic Twins Discordant for Diurnal Preference. Twin Res. Hum. Genet. 2015, 18, 662-669. [CrossRef]

107. Massart, R.; Freyburger, M.; Suderman, M.; Paquet, J.; El Helou, J.; Belanger-Nelson, E.; Rachalski, A.; Koumar, O.C.; Carrier, J.; Szyf, M.; et al. The genome-wide landscape of DNA methylation and hydroxymethylation in response to sleep deprivation impacts on synaptic plasticity genes. Transl. Psychiatry 2014, 4, e347. [CrossRef]

108. Huang, H.; Zhu, Y.; Eliot, M.N.; Knopik, V.S.; McGeary, J.E.; Carskadon, M.A.; Hart, A.C. Combining Human Epigenetics and Sleep Studies in Caenorhabditis elegans: A Cross-Species Approach for Finding Conserved Genes Regulating Sleep. Sleep 2017, 40, zsx063. [CrossRef]

109. Cedernaes, J.; Schonke, M.; Westholm, J.O.; Mi, J.; Chibalin, A.; Voisin, S.; Osler, M.; Vogel, H.; Hornaeus, K.; Dickson, S.L.; et al. Acute sleep loss results in tissue-specific alterations in genome-wide DNA methylation state and metabolic fuel utilization in humans. Sci. Adv. 2018, 4, eaar8590. [CrossRef]

110. Duan, R.; Liu, X.; Wang, T.; Wu, L.; Gao, X.; Zhang, Z. Histone Acetylation Regulation in Sleep Deprivation-Induced Spatial Memory Impairment. Neurochem. Res. 2016, 41, 2223-2232. [CrossRef]

111. Naruse, Y.; Oh-hashi, K.; Iijima, N.; Naruse, M.; Yoshioka, H.; Tanaka, M. Circadian and light-induced transcription of clock gene Per1 depends on histone acetylation and deacetylation. Mol. Cell Biol. 2004, 24, 6278-6287. [CrossRef] [PubMed] 
112. Davis, C.J.; Taishi, P.; Honn, K.A.; Koberstein, J.N.; Krueger, J.M. P2X7 receptors in body temperature, locomotor activity, and brain mRNA and lncRNA responses to sleep deprivation. Am. J. Physiol. Regul. Integr. Comp. Physiol. 2016, 311, R1004-R1012. [CrossRef] [PubMed]

113. Shende, V.R.; Neuendorff, N.; Earnest, D.J. Role of miR-142-3p in the post-transcriptional regulation of the clock gene Bmal1 in the mouse SCN. PLoS ONE 2013, 8, e65300. [CrossRef] [PubMed]

114. Nagel, R.; Clijsters, L.; Agami, R. The miRNA-192/194 cluster regulates the Period gene family and the circadian clock. FEBS J. 2009, 276, 5447-5455. [CrossRef] [PubMed]

115. Saus, E.; Soria, V.; Escaramis, G.; Vivarelli, F.; Crespo, J.M.; Kagerbauer, B.; Menchon, J.M.; Urretavizcaya, M.; Gratacos, M.; Estivill, X. Genetic variants and abnormal processing of pre-miR-182, a circadian clock modulator, in major depression patients with late insomnia. Hum. Mol. Genet. 2010, 19, 4017-4025. [CrossRef]

116. Traversy, G.; Chaput, J.P. Alcohol Consumption and Obesity: An Update. Curr. Obes. Rep. 2015, 4, 122-130. [CrossRef]

117. Halsted, C.H.; Villanueva, J.A.; Devlin, A.M.; Chandler, C.J. Metabolic interactions of alcohol and folate. J. Nutr. 2002, 132, 2367S-2372S. [CrossRef]

118. Haloul, M.; Vinjamuri, S.J.; Naquiallah, D.; Mirza, M.I.; Qureshi, M.; Hassan, C.; Masrur, M.; Bianco, F.M.; Frederick, P.; Cristoforo, G.P.; et al. Hyperhomocysteinemia and Low Folate and Vitamin B12 Are Associated with Vascular Dysfunction and Impaired Nitric Oxide Sensitivity in Morbidly Obese Patients. Nutrients 2020, 12, 2014. [CrossRef]

119. Zhang, X.; Kusumo, H.; Sakharkar, A.J.; Pandey, S.C.; Guizzetti, M. Regulation of DNA methylation by ethanol induces tissue plasminogen activator expression in astrocytes. J. Neurochem. 2014, 128, 344-349. [CrossRef] [PubMed]

120. Warnault, V.; Darcq, E.; Levine, A.; Barak, S.; Ron, D. Chromatin remodeling-a novel strategy to control excessive alcohol drinking Transl. Psychiatry 2013, 3, e231. [CrossRef]

121. Rodriguez-Araujo, G.; Nakagami, H.; Takami, Y.; Katsuya, T.; Akasaka, H.; Saitoh, S.; Shimamoto, K.; Morishita, R.; Rakugi, H.; Kaneda, Y. Low alpha-synuclein levels in the blood are associated with insulin resistance. Sci. Rep. 2015, 5, 12081. [CrossRef] [PubMed]

122. Ciafre, S.; Carito, V.; Ferraguti, G.; Greco, A.; Chaldakov, G.N.; Fiore, M.; Ceccanti, M. How alcohol drinking affects our genes: An epigenetic point of view. Biochem. Cell Biol. 2019, 97, 345-356. [CrossRef]

123. Ponomarev, I.; Wang, S.; Zhang, L.; Harris, R.A.; Mayfield, R.D. Gene coexpression networks in human brain identify epigenetic modifications in alcohol dependence. J. Neurosci. 2012, 32, 1884-1897. [CrossRef] [PubMed]

124. Qiang, M.; Denny, A.; Lieu, M.; Carreon, S.; Li, J. Histone H3K9 modifications are a local chromatin event involved in ethanolinduced neuroadaptation of the NR2B gene. Epigenetics 2011, 6, 1095-1104. [CrossRef] [PubMed]

125. Campion, J.; Milagro, F.I.; Goyenechea, E.; Martinez, J.A. TNF-alpha promoter methylation as a predictive biomarker for weight-loss response. Obesity 2009, 17, 1293-1297. [CrossRef] [PubMed]

126. Cordero, P.; Campion, J.; Milagro, F.I.; Goyenechea, E.; Steemburgo, T.; Javierre, B.M.; Martinez, J.A. Leptin and TNF-alpha promoter methylation levels measured by MSP could predict the response to a low-calorie diet. J. Physiol. Biochem. 2011, 67, 463-470. [CrossRef] [PubMed]

127. Bouchard, L.; Rabasa-Lhoret, R.; Faraj, M.; Lavoie, M.E.; Mill, J.; Perusse, L.; Vohl, M.C. Differential epigenomic and transcriptomic responses in subcutaneous adipose tissue between low and high responders to caloric restriction. Am. J. Clin. Nutr. 2010, 91, 309-320. [CrossRef]

128. Keller, M.; Yaskolka Meir, A.; Bernhart, S.H.; Gepner, Y.; Shelef, I.; Schwarzfuchs, D.; Tsaban, G.; Zelicha, H.; Hopp, L.; Muller, L.; et al. DNA methylation signature in blood mirrors successful weight-loss during lifestyle interventions: The CENTRAL trial. Genome Med. 2020, 12, 97. [CrossRef]

129. Milagro, F.I.; Gomez-Abellan, P.; Campion, J.; Martinez, J.A.; Ordovas, J.M.; Garaulet, M. CLOCK, PER2 and BMAL1 DNA methylation: Association with obesity and metabolic syndrome characteristics and monounsaturated fat intake. Chronobiol. Int. 2012, 29, 1180-1194. [CrossRef]

130. Uriarte, G.; Paternain, L.; Milagro, F.I.; Martinez, J.A.; Campion, J. Shifting to a control diet after a high-fat, high-sucrose diet intake induces epigenetic changes in retroperitoneal adipocytes of Wistar rats. J. Physiol. Biochem. 2013, 69, 601-611. [CrossRef]

131. Day, S.E.; Garcia, L.A.; Coletta, R.L.; Campbell, L.E.; Benjamin, T.R.; De Filippis, E.A.; Madura, J.A., II; Mandarino, L.J.; Roust, L.R.; Coletta, D.K. Alterations of sorbin and SH3 domain containing 3 (SORBS3) in human skeletal muscle following Roux-en-Y gastric bypass surgery. Clin. Epigenet. 2017, 9, 96. [CrossRef] [PubMed]

132. Barres, R.; Kirchner, H.; Rasmussen, M.; Yan, J.; Kantor, F.R.; Krook, A.; Naslund, E.; Zierath, J.R. Weight loss after gastric bypass surgery in human obesity remodels promoter methylation. Cell Rep. 2013, 3, 1020-1027. [CrossRef] [PubMed]

133. Benton, M.C.; Johnstone, A.; Eccles, D.; Harmon, B.; Hayes, M.T.; Lea, R.A.; Griffiths, L.; Hoffman, E.P.; Stubbs, R.S.; MacartneyCoxson, D. An analysis of DNA methylation in human adipose tissue reveals differential modification of obesity genes before and after gastric bypass and weight loss. Genome Biol. 2015, 16, 8. [CrossRef] [PubMed]

134. Ahrens, M.; Ammerpohl, O.; von Schonfels, W.; Kolarova, J.; Bens, S.; Itzel, T.; Teufel, A.; Herrmann, A.; Brosch, M.; Hinrichsen, H.; et al. DNA methylation analysis in nonalcoholic fatty liver disease suggests distinct disease-specific and remodeling signatures after bariatric surgery. Cell Metab. 2013, 18, 296-302. [CrossRef]

135. Morcillo, S.; Martin-Nunez, G.M.; Garcia-Serrano, S.; Gutierrez-Repiso, C.; Rodriguez-Pacheco, F.; Valdes, S.; Gonzalo, M.; Rojo-Martinez, G.; Moreno-Ruiz, F.J.; Rodriguez-Canete, A.; et al. Changes in SCD gene DNA methylation after bariatric surgery in morbidly obese patients are associated with free fatty acids. Sci. Rep. 2017, 7, 46292. [CrossRef] 
136. Nilsson, E.K.; Ernst, B.; Voisin, S.; Almen, M.S.; Benedict, C.; Mwinyi, J.; Fredriksson, R.; Schultes, B.; Schioth, H.B. Roux-en Y gastric bypass surgery induces genome-wide promoter-specific changes in DNA methylation in whole blood of obese patients. PLoS ONE 2015, 10, e0115186. [CrossRef]

137. Liang, Y.; Yu, B.; Wang, Y.; Qiao, Z.; Cao, T.; Zhang, P. Duodenal long noncoding RNAs are associated with glycemic control after bariatric surgery in high-fat diet-induced diabetic mice. Surg. Obes. Relat. Dis. 2017, 13, 1212-1226. [CrossRef]

138. Alkandari, A.; Ashrafian, H.; Sathyapalan, T.; Sedman, P.; Darzi, A.; Holmes, E.; Athanasiou, T.; Atkin, S.L.; Gooderham, N.J. Improved physiology and metabolic flux after Roux-en-Y gastric bypass is associated with temporal changes in the circulating microRNAome: A longitudinal study in humans. BMC Obes. 2018, 5, 20. [CrossRef]

139. Ortega, F.J.; Mercader, J.M.; Moreno-Navarrete, J.M.; Nonell, L.; Puigdecanet, E.; Rodriquez-Hermosa, J.I.; Rovira, O.; Xifra, G.; Guerra, E.; Moreno, M.; et al. Surgery-Induced Weight Loss Is Associated With the Downregulation of Genes Targeted by MicroRNAs in Adipose Tissue. J. Clin. Endocrinol. Metab. 2015, 100, E1467-E1476. [CrossRef]

140. Avery, L.B.; Bumpus, N.N. Valproic acid is a novel activator of AMP-activated protein kinase and decreases liver mass, hepatic fat accumulation, and serum glucose in obese mice. Mol. Pharmacol. 2014, 85, 1-10. [CrossRef]

141. Ozcan, U.; Yilmaz, E.; Ozcan, L.; Furuhashi, M.; Vaillancourt, E.; Smith, R.O.; Gorgun, C.Z.; Hotamisligil, G.S. Chemical chaperones reduce ER stress and restore glucose homeostasis in a mouse model of type 2 diabetes. Science 2006, 313, 1137-1140. [CrossRef] [PubMed]

142. Dahllof, M.S.; Christensen, D.P.; Lundh, M.; Dinarello, C.A.; Mascagni, P.; Grunnet, L.G.; Mandrup-Poulsen, T. The lysine deacetylase inhibitor Givinostat inhibits beta-cell IL-1beta induced IL-1beta transcription and processing. Islets 2012, 4, 417-422. [CrossRef] [PubMed]

143. Leoni, F.; Fossati, G.; Lewis, E.C.; Lee, J.K.; Porro, G.; Pagani, P.; Modena, D.; Moras, M.L.; Pozzi, P.; Reznikov, L.L.; et al. The histone deacetylase inhibitor ITF2357 reduces production of pro-inflammatory cytokines in vitro and systemic inflammation in vivo. Mol. Med. 2005, 11,1-15. [CrossRef]

144. Cabrera, S.M.; Colvin, S.C.; Tersey, S.A.; Maier, B.; Nadler, J.L.; Mirmira, R.G. Effects of combination therapy with dipeptidyl peptidase-IV and histone deacetylase inhibitors in the non-obese diabetic mouse model of type 1 diabetes. Clin. Exp. Immunol. 2013, 172, 375-382. [CrossRef]

145. Lewis, E.C.; Blaabjerg, L.; Storling, J.; Ronn, S.G.; Mascagni, P.; Dinarello, C.A.; Mandrup-Poulsen, T. The oral histone deacetylase inhibitor ITF2357 reduces cytokines and protects islet beta cells in vivo and in vitro. Mol. Med. 2011, 17, 369-377. [CrossRef]

146. Xiao, C.; Giacca, A.; Lewis, G.F. Sodium phenylbutyrate, a drug with known capacity to reduce endoplasmic reticulum stress, partially alleviates lipid-induced insulin resistance and beta-cell dysfunction in humans. Diabetes 2011, 60, 918-924. [CrossRef]

147. Arguelles, A.O.; Meruvu, S.; Bowman, J.D.; Choudhury, M. Are epigenetic drugs for diabetes and obesity at our door step? Drug Discov. Today 2016, 21, 499-509. [CrossRef]

148. Han, H.S.; Choi, D.; Choi, S.; Koo, S.H. Roles of protein arginine methyltransferases in the control of glucose metabolism. Endocrinol. Metab. 2014, 29, 435-440. [CrossRef]

149. vanLieshout, T.L.; Ljubicic, V. The emergence of protein arginine methyltransferases in skeletal muscle and metabolic disease. Am. J. Physiol. Endocrinol. Metab. 2019, 317, E1070-E1080. [CrossRef] [PubMed]

150. Choi, D.; Oh, K.J.; Han, H.S.; Yoon, Y.S.; Jung, C.Y.; Kim, S.T.; Koo, S.H. Protein arginine methyltransferase 1 regulates hepatic glucose production in a FoxO1-dependent manner. Hepatology 2012, 56, 1546-1556. [CrossRef]

151. Wang, J.; Chen, L.; Sinha, S.H.; Liang, Z.; Chai, H.; Muniyan, S.; Chou, Y.W.; Yang, C.; Yan, L.; Feng, Y.; et al. Pharmacophore-based virtual screening and biological evaluation of small molecule inhibitors for protein arginine methylation. J. Med. Chem. 2012, 55, 7978-7987. [CrossRef] [PubMed]

152. Hino, S.; Sakamoto, A.; Nagaoka, K.; Anan, K.; Wang, Y.; Mimasu, S.; Umehara, T.; Yokoyama, S.; Kosai, K.; Nakao, M. FAD-dependent lysine-specific demethylase-1 regulates cellular energy expenditure. Nat. Commun. 2012, 3, 758. [CrossRef] [PubMed]

153. Pan, D.; Mao, C.; Wang, Y.X. Suppression of gluconeogenic gene expression by LSD1-mediated histone demethylation. PLoS ONE 2013, 8, e66294. [CrossRef] [PubMed]

154. Chase, K.; Sharma, R.P. Epigenetic developmental programs and adipogenesis: Implications for psychotropic induced obesity. Epigenetics 2013, 8, 1133-1140. [CrossRef]

155. Yang, B.T.; Dayeh, T.A.; Volkov, P.A.; Kirkpatrick, C.L.; Malmgren, S.; Jing, X.; Renstrom, E.; Wollheim, C.B.; Nitert, M.D.; Ling, C. Increased DNA methylation and decreased expression of PDX-1 in pancreatic islets from patients with type 2 diabetes. Mol. Endocrinol. 2012, 26, 1203-1212. [CrossRef] [PubMed]

156. Halby, L.; Champion, C.; Senamaud-Beaufort, C.; Ajjan, S.; Drujon, T.; Rajavelu, A.; Ceccaldi, A.; Jurkowska, R.; Lequin, O.; Nelson, W.G.; et al. Rapid synthesis of new DNMT inhibitors derivatives of procainamide. Chembiochem 2012, 13, 157-165. [CrossRef]

157. Lee, B.H.; Yegnasubramanian, S.; Lin, X.; Nelson, W.G. Procainamide is a specific inhibitor of DNA methyltransferase 1. J. Biol. Chem. 2005, 280, 40749-40756. [CrossRef] 